\title{
Elevated ammonium concentrations from wastewater discharge depress primary productivity in the Sacramento River and the Northern San Francisco Estuary
}

\author{
Alexander E. Parker*, Richard C. Dugdale, Frances P. Wilkerson \\ Romberg Tiburon Center, San Francisco State University, 3152 Paradise Drive, Tiburon, CA 94920, United States
}

\section{A R T I C L E I N F O}

\section{Keywords:}

Ammonium

Phytoplankton

Wastewater

San Francisco Estuary

Eutrophication

Nitrification

\begin{abstract}
A B S T R A C T
Primary production in the Northern San Francisco Estuary (SFE) has been declining despite heavy loading of anthropogenic nutrients. The inorganic nitrogen $(\mathrm{N})$ loading comes primarily from municipal wastewater treatment plant (WTP) discharge as ammonium $\left(\mathrm{NH}_{4}\right)$. This study investigated the consequences for river and estuarine phytoplankton of the daily discharge of 15 metric tons $\mathrm{NH}_{4}-\mathrm{N}$ into the Sacramento River that feeds the SFE. Consistent patterns of nutrients and phytoplankton responses were observed during two 150-km transects made in spring 2009. Phytoplankton N productivity shifted from $\mathrm{NO}_{3}$ use upstream of the WTP to productivity based entirely upon $\mathrm{NH}_{4}$ downstream. Phytoplankton $\mathrm{NH}_{4}$ uptake declined downstream of the WTP as $\mathrm{NH}_{4}$ concentrations increased, suggesting $\mathrm{NH}_{4}$ inhibition. The reduced total $\mathrm{N}$ uptake downstream of the WTP was accompanied by a $60 \%$ decline in primary production. These findings indicate that increased anthropogenic $\mathrm{NH}_{4}$ may decrease estuarine primary production and increase export of $\mathrm{NH}_{4}$ to the coastal ocean.
\end{abstract}

(C) 2011 Elsevier Ltd. All rights reserved.

\section{Introduction}

Nutrient loading is increasing globally due to population growth and intensification of agriculture. Cultural eutrophication and the loading of aquatic systems with nitrogen $(\mathrm{N})$ and phosphorus $(P)$ have long been recognized as important drivers of ecosystem change. Generally, eutrophication is thought to degrade food webs and lead to increases in autotrophic biomass, including nuisance algal species, inefficient trophic transfer, stimulation of microbial activity and hypoxia. However, study of estuarine eutrophication globally for more than three decades has revealed a range of ecosystem responses to nutrient enrichment (Sharp, 2001). Increased nutrients may lead to eutrophication with undesirable consequences, but not in all cases (Cloern, 2001; Sharp et al., 2009). Rather than stimulating algal processes, negative effects on phytoplankton physiology have been observed (MacIsaac et al., 1979; Wilkerson et al., 2006). Reduction in primary productivity associated with anthropogenic ammonium $\left(\mathrm{NH}_{4}\right)$ loading has been reported, for example in the Delaware Estuary (Yoshiyama and Sharp, 2006) and a wastewater-dominated Canadian river (Waiser et al., 2011). The San Francisco Estuary (SFE) has also experienced declining primary productivity (Jassby et al., 2002) while receiving increased nutrient loading (Jassby, 2008). It is the largest estuary on the west coast of the US and highly impacted by the ur-

\footnotetext{
* Corresponding author. Tel.: +1 415338 3746; fax: +1 4154357120.

E-mail address: aeparker@sfsu.edu (A.E. Parker).
}

ban centers of the San Francisco Bay Area (San Francisco, Oakland and San Jose) and the City of Sacramento and receives nutrient inputs from more than 80 municipal wastewater treatment plants (WTPs) with varying levels of effluent treatment.

Increased loading of $\mathrm{NH}_{4}$ to the SFE is largely the product of the Clean Water Act requiring the conversion of WTP's to secondary treatment resulting in discharge of $\mathrm{N}$ as $\mathrm{NH}_{4}$. With the exception of Stockton, major cities in the Northern SFE and Delta do not carry out advanced secondary treatment and discharge $\mathrm{N}$ primarily in the form of $\mathrm{NH}_{4}$ rather than $\mathrm{NO}_{3}$. As of $2006,75 \%$ of the effluent released by Delta treatment plants was processed only to the secondary level (Brooks et al., 2011). Approximately $90 \%$ of the total $\mathrm{N}$ in the Northern SFE originates from a single point source, at the Sacramento Regional WTP (SRWTP), which discharges approximately 15 metric tons of $\mathrm{N}$ per day, largely as $\mathrm{NH}_{4}$, to the Sacramento River (Jassby, 2008).

Primary productivity in the SFE ranks towards the bottom of river-dominated estuaries (Boynton et al., 1982) and is thought to be regulated by turbidity and not nutrient supply (Cole and Cloern, 1984; Alpine and Cloern, 1988). However, recent studies suggest that in addition to light availability, increased nutrient loading (especially $\mathrm{NH}_{4}$ loading) acts as an additional estuarine "filter" (Cloern, 2001) that modulates primary production and results in alterations to the food web (Glibert, 2010; Glibert et al., 2011). Spring and summer phytoplankton blooms (traditionally diatoms; Cloern and Dufford, 2005) were previously a regular feature in the Northern SFE but rarely occur now (Kimmerer, 2006; 
Wilkerson et al., 2006; Jassby, 2008). Suppression of SFE spring blooms was linked to elevated $\mathrm{NH}_{4}$ concentrations (Wilkerson et al., 2006; Dugdale et al., 2007). When $\mathrm{NH}_{4}$ concentrations were above $4 \mu \mathrm{mol} \mathrm{N} \mathrm{L}{ }^{-1}$, high chlorophyll-a concentrations were not observed. Only when $\mathrm{NH}_{4}$ was decreased below $4 \mu \mathrm{mol} \mathrm{N} \mathrm{L}{ }^{-1}$, either through phytoplankton assimilation or through freshwater dilution, did phytoplankton access $\mathrm{NO}_{3}$, the larger pool of dissolved inorganic nitrogen (DIN) and accumulate chlorophyll-a biomass (Dugdale et al., 2007). A bloom sequence consists of two phases and only occurs when irradiance conditions are favorable for phytoplankton growth. In the first phase, $\mathrm{NH}_{4}$ is taken up by the phytoplankton resulting in reduction of ambient $\mathrm{NH}_{4}$ concentrations to below about $4 \mu \mathrm{mol} \mathrm{N} \mathrm{L}{ }^{-1}$. In the second phase, as $\mathrm{NO}_{3}$ is taken up, chlorophyll-a biomass accumulates and blooms result (Dugdale et al., 2007).

The requirement for use of $\mathrm{NO}_{3}$ to enable bloom formation in SFE, rather than $\mathrm{NH}_{4}$ seems counter-intuitive to the classical paradigm that phytoplankton "prefer" $\mathrm{NH}_{4}$ over $\mathrm{NO}_{3}$ as a result of lower energetic costs to the cell associated with protein synthesis (McCarthy et al., 1977). While the energetic argument is correct and applies in most batch culture experiments in the laboratory, in the SFE $\mathrm{NH}_{4}$ concentrations (e.g. winter mean in the Northern $\mathrm{SFE}=6.8 \mu \mathrm{mol} \mathrm{N} \mathrm{L}{ }^{-1}$; Wilkerson et al., 2006) are insufficient to fuel blooms. So for elevated chlorophyll-a concentrations, $\mathrm{NO}_{3}$ (e.g. $27.5 \mu \mathrm{mol} \mathrm{N} \mathrm{L}{ }^{-1}$; Wilkerson et al., 2006), the larger DIN pool, must be accessed. This can only be accomplished once $\mathrm{NH}_{4}$ is below some threshold above which it is inhibitory to $\mathrm{NO}_{3}$ uptake and assimilation. Raven et al. (1992) described how when both $\mathrm{NO}_{3}$ and $\mathrm{NH}_{4}$ are present (as in the SFE), phytoplankton will almost invariably use $\mathrm{NH}_{4}$ with complete suppression of $\mathrm{NO}_{3}$ uptake at $\mathrm{NH}_{4}$ concentrations of as little as $1-2 \mu \mathrm{mol} \mathrm{N} \mathrm{L}{ }^{-1}$. The suppression of phytoplankton $\mathrm{NO}_{3}$ uptake by $\mathrm{NH}_{4}$ has been documented in phytoplankton isolates (e.g. Cochlan and Harrison, 1991; Dortch, 1990; Lomas and Glibert, 1999; Maguer et al., 2007) and in natural communities (e.g. McCarthy et al., 1977; Collos et al., 1989; Cochlan and Bronk, 2003; L'Helguen et al., 2008).

The impact of $\mathrm{NH}_{4}$ suppression of $\mathrm{NO}_{3}$ uptake and the reduction of phytoplankton blooms and primary production is particularly important for the Northern SFE, where food limitation has been demonstrated for zooplankton (Mueller-Solger et al., 2002) and fish species (Bennett and Moyle, 1996) and may be in part responsible for an overall "pelagic organism decline" (Sommer et al., 2007). Glibert (2010) described how the decline in fish may be closely linked to historical changes in nutrient loadings, especially of $\mathrm{NH}_{4}$ and $\mathrm{P}$ (Van Nieuwenhuse, 2007). Although the Sacramento River that feeds the Northern SFE has been considered a significant source of organic matter for the Northern SFE (Jassby et al., 2002; Sobczak et al., 2005), little is known or documented about productivity of the phytoplankton in the river and the impact of $\mathrm{N}$ loading on their physiology. The goals of this study were to: (1) understand the distribution and biological processing of different forms of DIN in the Sacramento River and (2) describe how discharge of wastewater $\mathrm{NH}_{4}$ effluent influences phytoplankton biomass and primary productivity in the Sacramento River and downstream to the Northern SFE.

\section{Materials and methods}

\subsection{River and estuary surveys}

Two, 150-km surveys of the Sacramento River and Northern San Francisco Estuary were made on 26-27 March and 23-24 April 2009 using the R/V Questuary. During each survey 21 geographically fixed stations were sampled on the outgoing tide from upstream to downstream (Fig. 1 and Table 1). For analysis the

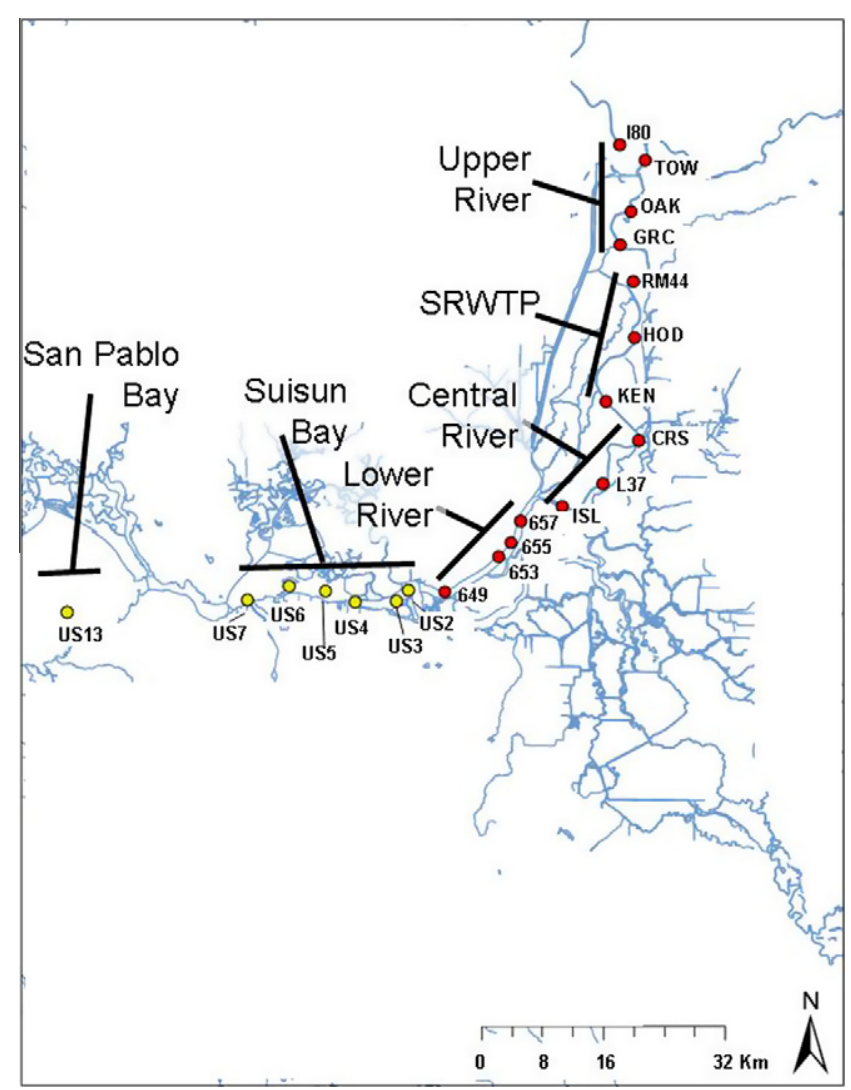

Fig. 1. Study region of the Sacramento River and San Francisco Estuary, CA showing sampling stations and river and Northern estuary transect regions.

transect was divided into six regions based on geographic location, ambient $\mathrm{NH}_{4}$ and chlorophyll-a concentrations. The Upper River region included the four stations (I80, TOW, OAK and GRC) above the Sacramento Regional Wastewater Treatment Plant (SRWTP) and was characterized by low $\mathrm{NH}_{4}$ concentrations $\left(\leqslant 1 \mu \mathrm{mol} \mathrm{N} \mathrm{L}{ }^{-1}\right)$. The SRWTP region included three stations (RM44, HOD and KEN), that were the closest geographically to the SRWTP and had elevated $\mathrm{NH}_{4}$; RM44 is the station closest to the SRWTP discharge. The Central River region encompassed three stations (CRS, L37 and ISL) and also exhibited high $\mathrm{NH}_{4}$ concentrations. The Lower River region included four stations (657, 655, 653 and 649) and was marked by declines in both $\mathrm{NH}_{4}$ and chlorophyll-a concentrations. In the Northern estuary, Suisun Bay included six stations (US2, US3, US4, US5, US6 and US7) and San Pablo Bay was represented by a single station (US13). Stations south of Isleton (ISL) were identical to monthly water quality monitoring stations sampled by the US Geological Survey (USGS) (Jassby et al., 1997; http:// sfbay.wr.usgs.gov/access/wqdata/index.html). River distances (km) were calculated from the SRWTP (i.e. at $0 \mathrm{~km}$ ) with stations upstream of the SRWTP being negative. Sacramento River discharge was obtained from the California Department of Water Resources Dayflow algorithm (http://www.water.ca.gov/dayflow/). SRWTP daily effluent discharge was obtained from the California Central Valley Regional Water Quality Control Board.

At each station, a Seabird Electronics SB-32 rosette mounted with six 3-L Niskin bottles and fitted with a Seabird SBE-19 plus CTD was deployed to collect vertical profiles of temperature and salinity and collect surface water samples. In the freshwater regions the salinity was reported as electrical conductivity ( $\mu S$ $\mathrm{cm}^{-1}$ ) while in the Northern SFE salinity was reported using the practical salinity scale (pss). Turbidity was measured with a D\&A Instruments Optical Backscatter (Model OBS-3, S/N 937) sensor 
Table 1

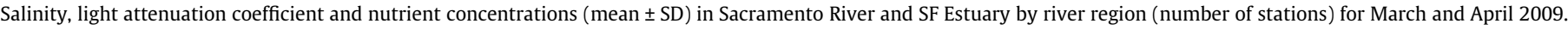

\begin{tabular}{|c|c|c|c|c|c|c|c|c|c|c|}
\hline River Region & $\begin{array}{l}\mathrm{EC} \\
\left(\mu \mathrm{S} \mathrm{cm} \mathrm{cm}^{-1}\right)\end{array}$ & $\begin{array}{l}k \\
\left(\mathrm{~m}^{-1}\right)\end{array}$ & $\begin{array}{l}\mathrm{NO}_{3} \\
\left(\mu \mathrm{mol} \mathrm{L}{ }^{-1}\right)\end{array}$ & $\begin{array}{l}\mathrm{NO}_{2} \\
\left(\mu \mathrm{mol} \mathrm{L}{ }^{-1}\right)\end{array}$ & $\begin{array}{l}\mathrm{NH}_{4} \\
\left(\mu \mathrm{mol} \mathrm{L}{ }^{-1}\right)\end{array}$ & $\begin{array}{l}\text { DIN } \\
\left(\mu \mathrm{mol} \mathrm{L} \mathrm{L}^{-1}\right)\end{array}$ & $\begin{array}{l}\mathrm{NH}_{4} \text { as \%DIN } \\
(\%)\end{array}$ & $\begin{array}{l}\text { Urea } \\
\left(\mu \mathrm{mol} \mathrm{L}{ }^{-1}\right)\end{array}$ & $\begin{array}{l}\text { SRP } \\
\left(\mu \mathrm{mol} \mathrm{L}^{-1}\right)\end{array}$ & $\begin{array}{l}\mathrm{Si}(\mathrm{OH})_{4} \\
\left(\mu \mathrm{mol} \mathrm{L}^{-1}\right)\end{array}$ \\
\hline \multicolumn{11}{|l|}{ March 2009} \\
\hline Upper River (4) & $86 \pm 8$ & $2.5 \pm 0.5$ & $13.08 \pm 0.59$ & $0.12 \pm 0.02$ & $0.25 \pm 0.09$ & $13.81 \pm 0.60$ & 1.8 & $0.36 \pm 0.07$ & $1.37 \pm 0.12$ & $343 \pm 19$ \\
\hline SRWTP (3) & $85 \pm 5$ & $3.2 \pm 0.1$ & $13.85 \pm 1.46$ & $0.15 \pm 0.08$ & $29.58 \pm 10.24$ & $43.87 \pm 12.05$ & 64.2 & $0.29 \pm 0.38$ & $2.94 \pm 0.95$ & $336 \pm 4$ \\
\hline Central River (3) & $86 \pm 2$ & $3.5 \pm 0.2$ & $17.21 \pm 2.16$ & $0.35 \pm 0.09$ & $34.50 \pm 8.29$ & $52.43 \pm 9.04$ & 66.8 & $0.44 \pm 0.38$ & $3.14 \pm 0.39$ & $333 \pm 11$ \\
\hline Lower River (4) & $117 \pm 1$ & $1.8 \pm 0.3$ & $29.07 \pm 1.24$ & $0.95 \pm 0.10$ & $13.76 \pm 3.17$ & $44.26 \pm 3.93$ & 31.2 & $0.44 \pm 0.22$ & $2.98 \pm 0.16$ & $350 \pm 4$ \\
\hline Suisun Bay (6) & $0.9 \pm 1.3^{*}$ & $1.3 \pm 0.1$ & $32.94 \pm 0.5$ & $1.19 \pm 0.29$ & $8.54 \pm 1.20$ & $43.23 \pm 1.70$ & 19.7 & $0.56 \pm 0.40$ & $2.96 \pm 0.11$ & $327 \pm 14$ \\
\hline San Pablo Bay (1) & $23.1^{*}$ & 2.5 & 21.85 & 1.03 & 2.24 & 26.01 & 8.6 & 0.84 & 2.33 & 138 \\
\hline \multicolumn{11}{|l|}{ April 2009} \\
\hline Upper River (4) & $113 \pm 11$ & $1.0 \pm 0.4$ & $2.06 \pm 0.54$ & $0.14 \pm 0.01$ & $0.58 \pm 0.23$ & $2.78 \pm 0.73$ & 20.4 & $0.10 \pm 0.20$ & $0.44 \pm 0.10$ & $270 \pm 34$ \\
\hline SRWTP (3) & $123 \pm 4$ & $1.4 \pm 0.3$ & $4.57 \pm 0.95$ & $0.21 \pm 0.10$ & $36.02 \pm 13.47$ & $40.80 \pm 14.38$ & 86.9 & $0.26 \pm 0.25$ & $1.70 \pm 0.20$ & $276 \pm 13$ \\
\hline Central River (3) & $123 \pm 4$ & $1.1 \pm 0.2$ & $7.73 \pm 2.08$ & $0.42 \pm 0.10$ & $31.84 \pm 13.35$ & $39.99 \pm 15.19$ & 81.4 & $0.24 \pm 0.14$ & $1.81 \pm 0.43$ & $271 \pm 10$ \\
\hline Lower River (4) & $144 \pm 2$ & $2.5 \pm 0.7$ & $18.29 \pm 1.96$ & $0.93 \pm 0.07$ & $14.57 \pm 1.46$ & $33.79 \pm 0.58$ & 44.6 & $0.08 \pm 0.06$ & $1.84 \pm 0.15$ & $276 \pm 16$ \\
\hline Suisun Bay (6) & $2.6 \pm 2.5^{*}$ & $3.0 . \pm 0.4$ & $30.71 \pm 2.35$ & $1.35 \pm 0.30$ & $7.72 \pm 0.96$ & $39.78 \pm 3.15$ & 19.4 & $0.46 \pm 0.46$ & $2.32 \pm 0.23$ & $259 \pm 19$ \\
\hline San Pablo Bay (1) & $24.6^{*}$ & 1.7 & 28.00 & 0.78 & 3.13 & 31.13 & 10.0 & 0.10 & 2.32 & 72 \\
\hline
\end{tabular}

" Indicated salinity (dimensionless) reported on the practical salinity scale.

and reported as nephelometric turbidity units (ntu). The rosette was also equipped with a LiCor $4 \Pi$ photosynthetically active radiation (PAR) sensor. Light attenuation, $k\left(\mathrm{~m}^{-1}\right)$, was calculated by linear regression of $\log$ transformed PAR versus depth.

\subsection{Detailed methods}

20-ml dissolved inorganic carbon (DIC) samples were collected in glass scintillation vials, preserved according to Sharp et al. (2009) with $200 \mu \mathrm{L} \mathrm{5 \%} \mathrm{w/v} \mathrm{HgCl}_{2}$ and stored in the dark. These data were used for calculating ${ }^{13} \mathrm{C}$ uptake rates. DIC analysis was completed within 1 week using a Monterey Bay Research Institute clone DIC analyzer with acid-sparging and a LiCor nondispersive infrared detector (Model 6252) (Friederich et al., 2002; Parker et al., 2006). Water samples for nutrient analysis were immediately filtered through Whatman GF/F filters using a 50-ml syringe and stored on dry ice in 20-ml HDPE scintillation vials or 50-ml centrifuge tubes. All nutrient analyses, except for $\mathrm{NH}_{4}$ and urea-N, were performed on a Bran and Luebbe AutoAnalyzer II. $\mathrm{NO}_{3}, \mathrm{NO}_{2}$ and soluble reactive phosphorus (SRP) were analyzed using Whitledge et al. (1981) and $\mathrm{Si}(\mathrm{OH})_{4}$ using Bran and Luebbe (1999) and MacDonald et al. (1986). Twenty-five milliliter samples for $\mathrm{NH}_{4}$ determination were collected separately into 50-ml centrifuge tubes after filtration (Wilkerson et al., 2006). These samples were also immediately frozen for later analysis by the colorimetric method of Solorzano (1969) using a Hewlett Packard diode array spectrophotometer and $10-\mathrm{cm}$ path length cell. Samples for urea were prepared in the same manner as $\mathrm{NH}_{4}$ samples with analysis performed according to Revilla et al. (2005).

Two size fractions were collected for analysis of extracted chlorophyll-a concentration using 25-mm Whatman GF/F filters (nominally cells $>0.7-\mu \mathrm{m}$, referred to here as the "whole community" fraction) and $25-\mathrm{mm}$ diameter $5.0-\mu \mathrm{m}$ Nuclepore pore-sized polycarbonate filters. Sample volumes were selected to minimize filtration times to $<10$ min using a low vacuum $(<250 \mathrm{~mm} \mathrm{Hg})$ and varied between 50 and $200 \mathrm{ml}$. Filters were stored dry at $4{ }^{\circ} \mathrm{C}$ for up to one week. Prior to analysis, chlorophyll-a was extracted from the filters in $90 \%$ acetone for 24 -h at $4{ }^{\circ} \mathrm{C}$ according to Arar and Collins (1992). Analysis was performed fluorometrically with a Turner Designs Model 10-AU using 10\% hydrochloric acid to correct for and measure phaeophytin. The fluorometer was calibrated with commercially available chlorophyll-a (Turners Designs chlorophyll-a standard). Phaeophytin concentrations were calculated according to Holm-Hansen and Riemann (1978).

Phytoplankton carbon productivity and nitrogen $\left(\mathrm{NO}_{3}\right.$ and $\left.\mathrm{NH}_{4}\right)$ uptake rates were estimated using dual-labeled ${ }^{13} \mathrm{C} /{ }^{15} \mathrm{~N}$ tracer incubations (Legendre and Gosselin, 1996; Parker, 2005; Parker et al., submitted for publication). Two, 160-ml clear polycarbonate incubation bottles were filled with sample water at each station; to one incubation bottle $\mathrm{H}^{13} \mathrm{CO}_{3}$ and ${ }^{15} \mathrm{NH}_{4} \mathrm{Cl}$ were added and to the other, $\mathrm{H}^{13} \mathrm{CO}_{3}$ and $\mathrm{K}^{15} \mathrm{NO}_{3}$ (all stable isotope stocks contained 99 at\%, Cambridge Isotope Laboratories). Isotope additions were kept to ca $10 \%$ of ambient concentrations. Incubations were performed over 24-h on board in a flowing river water incubator covered with one layer of window screening to simulate $50 \%$ of ambient surface PAR. A 24-h period was selected so that incubations could be started throughout the day. Because DIN concentrations were generally high ( $>>2 \mu \mathrm{mol} \mathrm{N} \mathrm{L}{ }^{-1}$ ) N-substrate limitation during incubations was unlikely at most stations as phytoplankton

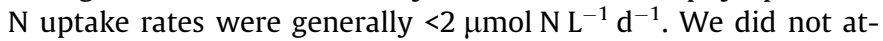
tempt to account for $\mathrm{NH}_{4}$ regeneration and reported $\mathrm{NH}_{4}$ uptake rates should be considered conservative. Incubations were terminated by gentle vacuum filtration onto pre-combusted $\left(450{ }^{\circ} \mathrm{C}\right.$ for 4-h) $25-\mathrm{mm}$ diameter GF/F filters. Phytoplankton ${ }^{13} \mathrm{C}$ and ${ }^{15} \mathrm{~N}$ enrichment, concentrations of particulate carbon (POC) and nitrogen (PON) were measured on a PDZ Europa 20/20 gas chromatograph - mass spectrometer. Carbon and nitrogen uptake rates $(\rho$, $\mu \mathrm{mol} \mathrm{L}{ }^{-1} \mathrm{~d}^{-1}$ ) and biomass-specific uptake (normalized to either POC or PON, V, $\mathrm{d}^{-1}$ ) were calculated according to Dugdale and Wilkerson (1986). Phytoplankton carbon uptake rates $(\rho C)$ are referred to as "primary production" as is the convention for carbon uptake studies.

During this study phytoplankton $\mathrm{C}$ and $\mathrm{N}$ uptake rates were measured only on surface samples incubated at $50 \%$ of surface PAR. To estimate a maximum depth-integrated $\mathrm{NH}_{4}$ uptake rate for the SRWTP region, we multiplied the average surface $\mathrm{NH}_{4}$ uptake rate by the euphotic zone depth. This procedure assumes a constant uptake throughout the euphotic zone and is likely an overestimate. The depth integrated water column $\mathrm{NH}_{4}$ concentration at the SRWTP region was calculated using the mean surface concentration for the SRWTP region multiplied by the depth at the SRWTP station RM44 (8 m), assuming full vertical mixing.

To estimate microbial nitrification rates, a mass balance approach was used that calculated the increase in $\mathrm{NO}_{3}$ concentrations measured between the SRWTP region (at KEN, Fig. 1) $\left(\mathrm{NO}_{3}=\right.$ $15.62 \mu \mathrm{mol} \mathrm{N} \mathrm{L}{ }^{-1}$ ) and downstream in Suisun Bay at the location with the maximum $\mathrm{NO}_{3}$ concentration (US5 $=34.00 \mu \mathrm{mol} \mathrm{N} \mathrm{L}{ }^{-1}$ ). Using the mean March 2009 Sacramento River flow rate $\left(850 \mathrm{~m}^{3} \mathrm{~s}^{-1}\right.$, Fig. 2), the calculated river flow speed was $\sim 13 \mathrm{~km} \mathrm{~d}^{-1}$. Assuming no algal uptake of $\mathrm{NH}_{4}$ and quasi-steady state conditions, the difference in $\mathrm{NO}_{3}$ concentrations divided by the transit time between the locations was used to calculate a rate 


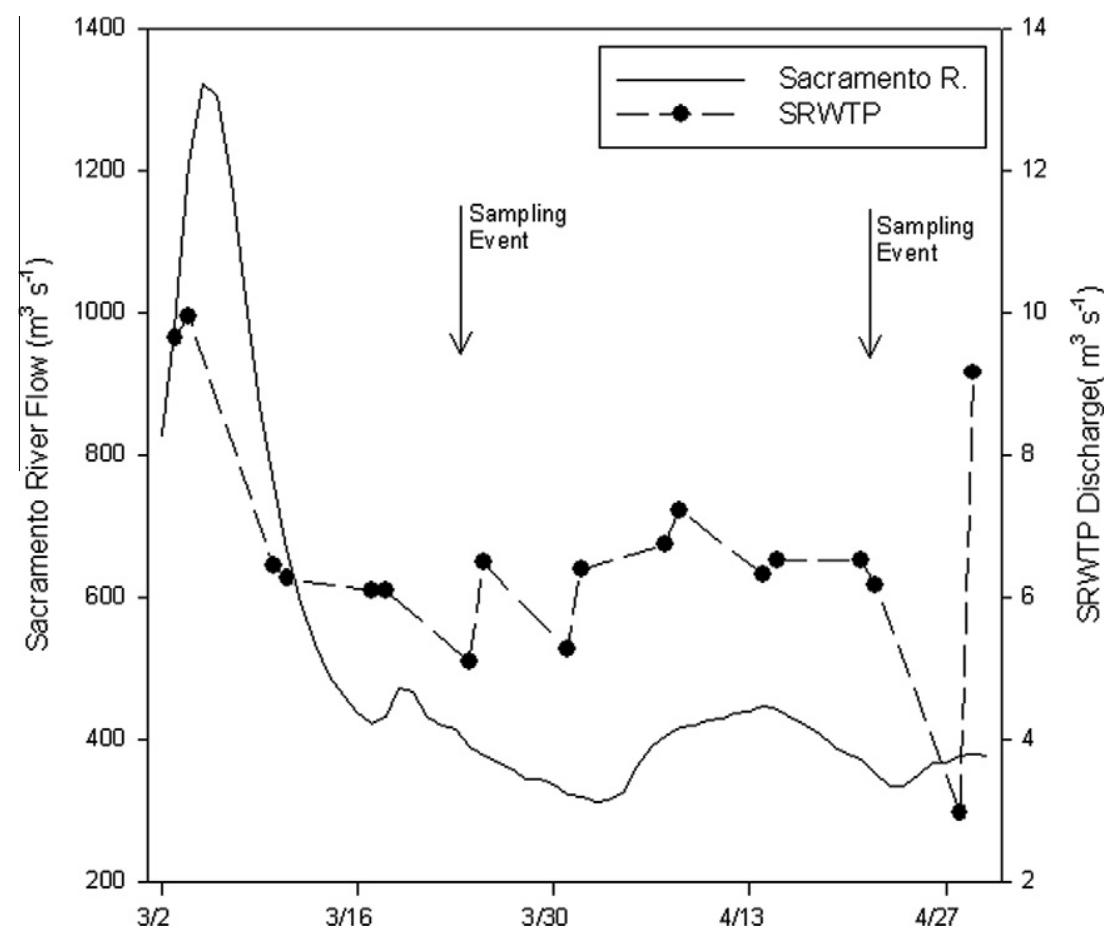

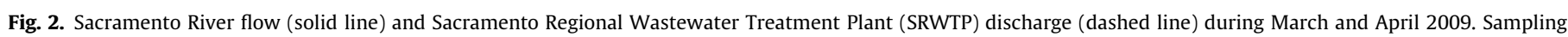
event dates are indicated with arrows.

of $\mathrm{NO}_{3}$ appearance (i.e. nitrification). An alternative approach from Yool et al. (2007) used an average specific nitrification factor to predict the $\mu \mathrm{mol} \mathrm{NO}_{3} \mathrm{~L}^{-1}$ produced per $\mu \mathrm{mol} \mathrm{NH}_{4} \mathrm{~L}^{-1}$ per day. This factor was applied to the maximal $\mathrm{NH}_{4}$ concentration $(40 \mu \mathrm{mol}$ $\mathrm{N} \mathrm{L}^{-1}$ ) in the Sacramento River (at KEN).

\section{Results}

3.1. River and SRWTP discharge, temperature, salinity, turbidity and light attenuation

Based on the California Water Year Hydrologic Classification Index (http://cdec.water.ca.gov/cgi-progs/iodir/wsihist), 2009 was classified as a "dry" year. Sacramento River flow during March and April varied between 311 and $1322 \mathrm{~m}^{3} \mathrm{~s}^{-1}$ with higher flow at the beginning of March (Fig. 2). SRWTP discharge represented roughly one percent of river flow $\left(3-10 \mathrm{~m}^{3} \mathrm{~s}^{-1}\right)$. Mean nitrogen load from the SRWTP was $15.5 \pm 2.9$ tons $\mathrm{N} \mathrm{d}^{-1}$ during the study period (Central Valley Regional Water Quality Control Board, personal communication). Surface water temperature was similar between stations during the March survey, with an average $( \pm S D)$ water temperature of $14.2 \pm 0.3^{\circ} \mathrm{C}$ (data not shown). During April, surface water temperatures were warmest in the Upper River, SRWTP and Central River regions (averaging $\left.18.9 \pm 0.4{ }^{\circ} \mathrm{C} ; n=10\right)$ and in the Lower River region $\left(18.4 \pm 0.6^{\circ} \mathrm{C}\right.$, $n=4)$ and coldest in Suisun and San Pablo Bays $\left(16.8 \pm 1.0^{\circ} \mathrm{C}\right.$, $n=7$ ). In April, mean electrical conductivity (EC) was $113 \pm$ $11 \mu \mathrm{S} \mathrm{cm}^{-1}$ in Upper River and $123 \pm 4 \mu \mathrm{S} \mathrm{cm}^{-1}$ for both SRWTP, and Central River regions and then increased within the Lower River $\left(144 \mu \mathrm{S} \mathrm{cm}^{-1}\right)$ and into Suisun Bay (2.6 psu) (Table 1). The downstream decrease in water temperatures with increased salinity during April was due to mixing with ocean water. During March, EC showed a similar pattern although values were generally lower. Vertical profiles of temperature, salinity and turbidity suggest a well mixed water column in the Upper River (I-80), SRWTP (RM44), Central River (L37) and Lower River (US657) re- gions (Fig. 3). Stations within Suisun Bay (US4) and San Pablo Bay (US13) showed some vertical structure, with slightly colder temperatures and higher salinity with depth. Turbidity showed increases at depth at these two stations suggesting higher suspended sediment loads.

Light attenuation coefficients for the different regions varied between $1.3-3.5 \mathrm{~m}^{-1}$ for March and $1.0-3.0 \mathrm{~m}^{-1}$ for April (Table 1 ). Using all data from March and April transects, $k$ and turbidity were strongly correlated $\left(k=12.2 * \mathrm{ntu}+0.62 ; \quad r^{2}=0.91, \quad p<0.0001\right.$, $n=42$; data not shown). Similar analysis of $k$ versus chlorophylla did not show a significant relationship $\left(r^{2}=0.02, p=0.65\right.$, $n=42$, data not shown), indicating that phytoplankton biomass and light attenuation were not related. Because sampling was generally restricted to the main navigational channel of the estuary and river, the ratio of water column depth to euphotic zone depth (i.e. to $1 \%$ of surface PAR) was relatively high indicating generally poor average light conditions for phytoplankton throughout the well mixed water column. This ratio averaged 2.5 for the Upper River, SRWTP and Central River regions, 5.9 for the Lower River region, 10.8 for Suisun Bay and 4.8 for San Pablo Bay. At two locations (I80 and ISL) during April the water column depth $(<5 \mathrm{~m})$ was less than the euphotic zone depth such that sunlight likely penetrated to the river bottom, providing a more favorable light environment for phytoplankton.

\subsection{Nutrient concentrations}

The effect of the SRWTP effluent on $\mathrm{NH}_{4}$ concentrations was apparent during March and April, first as a large step increase in $\mathrm{NH}_{4}$ between the Upper River and the SRWTP region at station RM44 followed by peak values in the Central River region (Fig. 4A, B). $\mathrm{NH}_{4}$ concentrations declined going downstream to the Lower River region and remained relatively low through Suisun Bay. $\mathrm{NO}_{3}$ concentrations remained relatively constant from the Upper River, SRWTP and Central River regions, and then increased rapidly to the Lower River. Dissolved inorganic nitrogen (DIN) concentrations were lower in all transect regions during April 
$1-80$

Temperature (C)

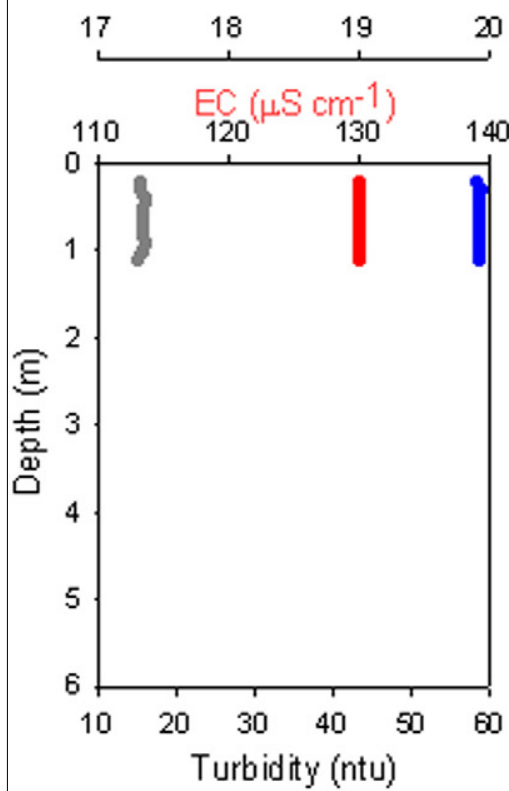

US657

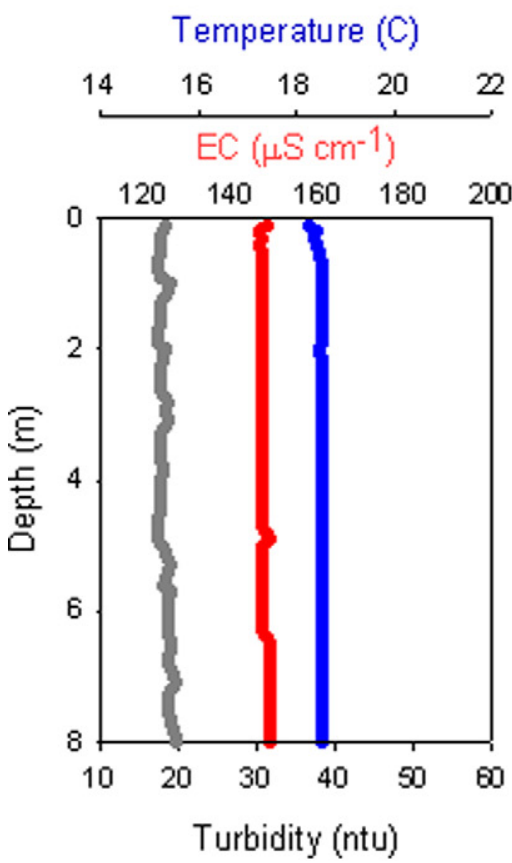

RM-44

Temperature (C)

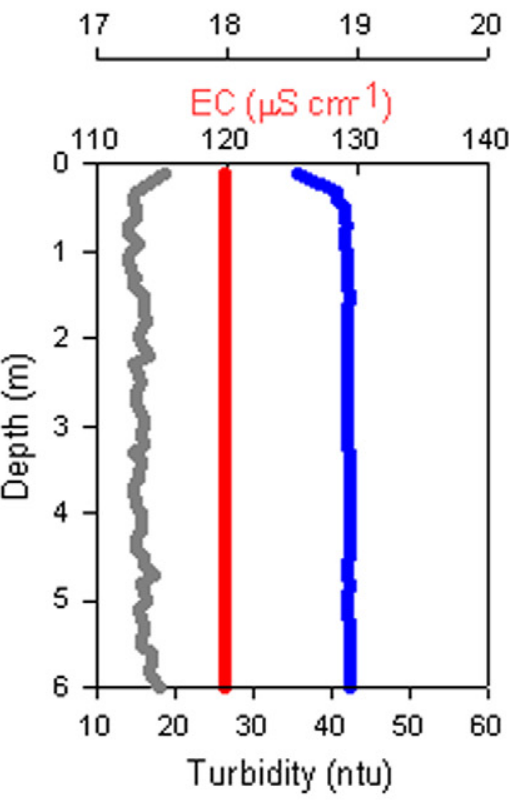

US4

Temperature (C)
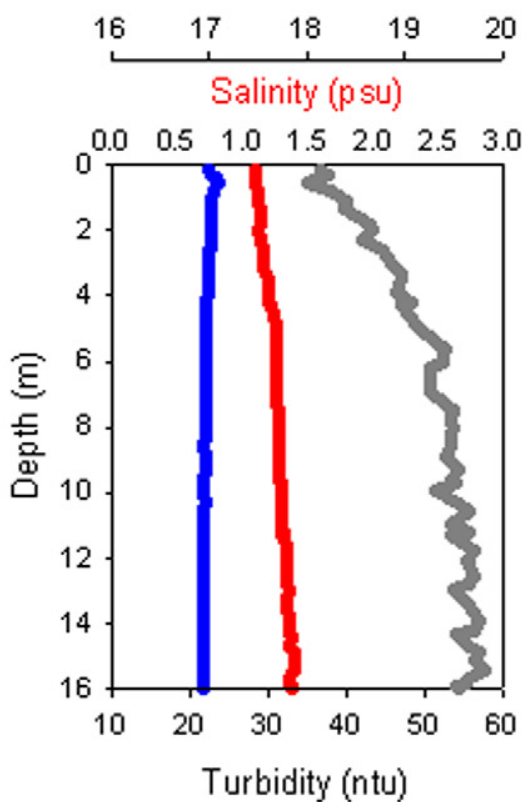

L37

Temperature (C)

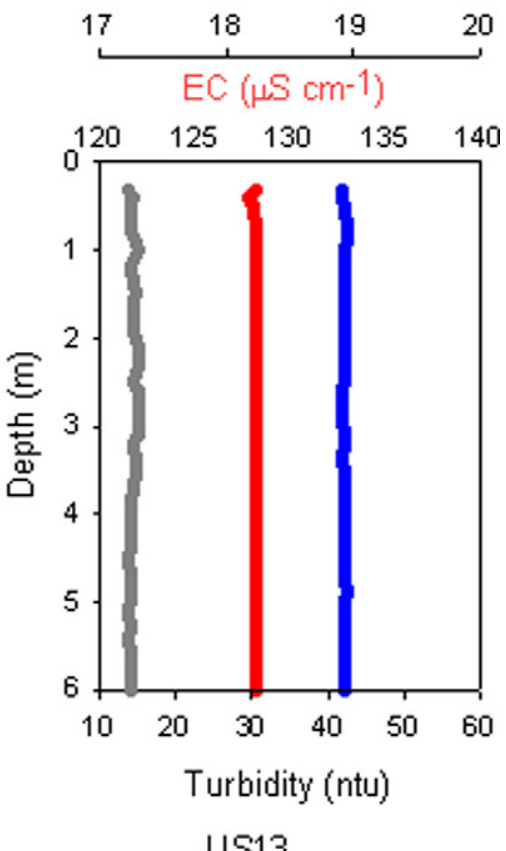

US13

Temperature (C)

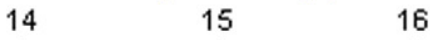

Salinity ( $\mathrm{psu}$ )

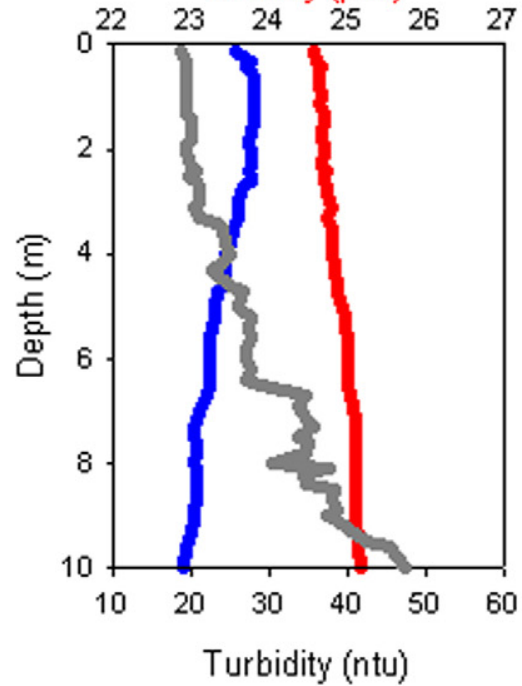

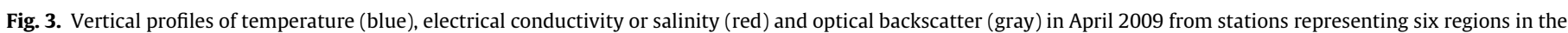
Sacramento River and the Northern San Francisco Estuary.

compared to March except for San Pablo Bay. This difference between months was most pronounced in the Upper River Region where the DIN concentration (mostly $\mathrm{NO}_{3}$ ) in March was 4-fold greater than April (Table 1 and Fig. 4A, B). In the Upper River during both months, $\mathrm{NH}_{4}$ was low $\left(<1 \mu \mathrm{mol} \mathrm{N} \mathrm{L}^{-1}\right)$, but since $\mathrm{NO}_{3}$ varied between months in the Upper River, $\mathrm{NH}_{4}$ contributed between $1.8 \%$ in March to $20.4 \%$ in April to the DIN pool (Table 1 ). In the SRWTP and Central River regions the percent $\mathrm{NH}_{4}$ increased from $64.2 \%$ to $86.9 \%$. The contribution of $\mathrm{NH}_{4}$ to total DIN decreased to $31.2 \%$ to $44.6 \%$ in the Lower River region, to $<20 \%$ in Suisun Bay and to $\leqslant 10 \%$ in San Pablo Bay.
$\mathrm{NO}_{2}$ concentrations were generally low $\left(<2 \mu \mathrm{mol} \mathrm{N} \mathrm{L}{ }^{-1}\right)$ relative to $\mathrm{NO}_{3}$ and $\mathrm{NH}_{4}$ along both surveys (Table 1 and Fig. 4A, B). However, a consistent increase in $\mathrm{NO}_{2}$ occurred within the Lower River and Suisun Bay (Table 1 and Fig. 4A, B). The highest region-mean $\mathrm{NO}_{2}$ concentrations (1.19 and $1.35 \mu \mathrm{mol} \mathrm{N} \mathrm{L}{ }^{-1}$, for March and April, respectively) were observed within the Suisun Bay region (Table 1). Urea concentrations were always $<1.0 \mu \mathrm{mol} \mathrm{N} \mathrm{L}^{-1}$ (Table 1 ). A large increase in SRP concentration was observed during both surveys at RM44, suggesting that the SRWTP was a significant source of SRP for the river (Table 1 and Fig. 4A, B). Downstream SRP concentrations followed the downstream changes in DIN during both 

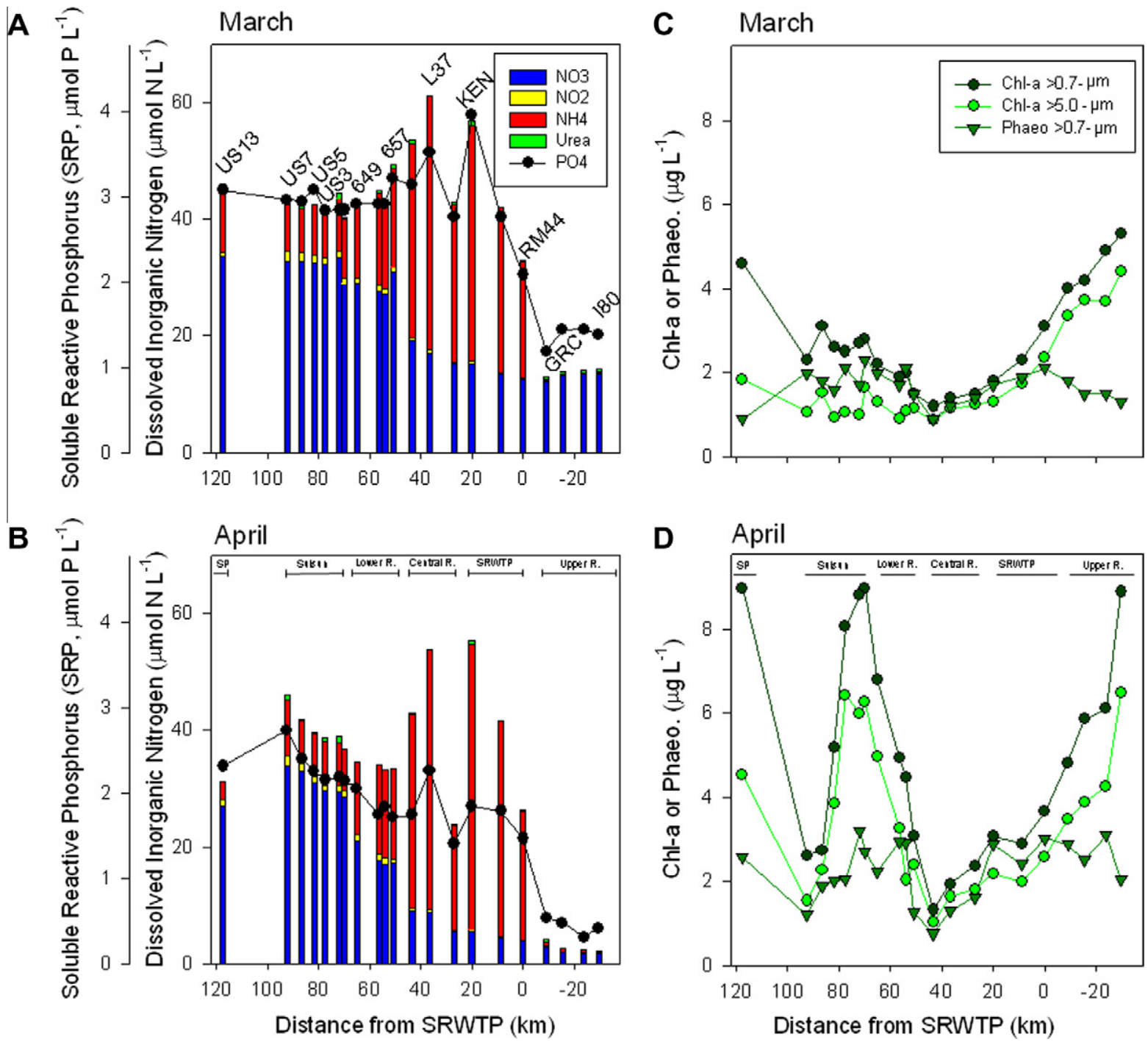

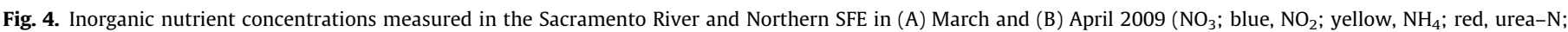

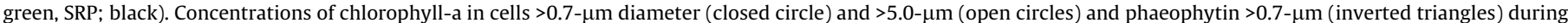
(C) March and (D) April 2009.

months. Silicate concentrations declined with distance along the transect, and were generally inversely related to salinity.

\subsection{Chlorophyll-a concentrations}

The downstream distribution of chlorophyll-a followed similar patterns for both surveys (Fig. 4C and D) but concentrations were higher during April compared to March (Table 2 and Fig. 4C, D). Chlorophyll-a for the whole community $(>0.7-\mu \mathrm{m}$ fraction) decreased downstream from the Upper River region (4.6 \pm 0.6 and $6.4 \pm 1.7 \mu \mathrm{g} \mathrm{L}^{-1}$ in March and April, respectively) through the Central River region where the lowest chlorophyll-a concentrations were observed $\left(1.4 \pm 0.2\right.$ and $1.9 \pm 0.5 \mu \mathrm{g} \mathrm{L}^{-1}$; Table 2 and Fig. $4 \mathrm{C}$, D). Chlorophyll-a then increased in the seaward direction from the Lower River region to Suisun Bay and San Pablo Bay (maximum values of 4.6 and $9.0 \mu \mathrm{g} \mathrm{L}^{-1}$ at San Pablo Bay, Table 2 and Fig. 4C, D). Chlorophyll-a in the larger cells (i.e. $>5-\mu \mathrm{m}$ in diameter) showed a similar pattern to whole community chlorophyll-a along both surveys (Fig. 4C and D). At most locations the larger cell-sized fraction contributed more than $60 \%$ to the total chlorophyll-a (Table 2). However, in March, in the Lower River region and seaward, the percentage of chlorophyll-a in the larger cells was lower (Table 2). Phaeophytin concentrations paralleled that of chloro- phyll-a throughout most of the surveys except in the Upper River region where they decreased as chlorophyll-a increased upstream (Fig. 4C and D).

\subsection{Primary production and nutrient uptake}

Consistent with chlorophyll-a concentrations, rates of primary production $(\rho C)$ were lower during the March survey compared to April likely in response to the seasonal increase in solar irradiance (Table 2 and Fig. 5A, B). The primary production pattern followed the changes in the nitrogen source being accessed and taken up (Fig. 5A and B). The highest river primary production rates were observed in the Upper River region where $\mathrm{NO}_{3}$ was being taken up (Fig. 5A and B) and. $\mathrm{NH}_{4}$ concentrations were low (Fig. 5C and D). Accompanying elevated $\mathrm{NH}_{4}$ concentrations in the SRWTP region, phytoplankton $\mathrm{NO}_{3}$ uptake ceased and phytoplankton $\mathrm{NH}_{4}$ uptake increased (Fig. 5A and B). With the elevated $\mathrm{NH}_{4}$ concentrations downstream of the SRWTP (Fig. 5C and D), phytoplankton $\mathrm{NO}_{3}$ uptake was negligible (Fig. 5A and B). Primary production and phytoplankton $\mathrm{NH}_{4}$ uptake declined downstream to minima within the Lower River region in March and the Central River region during April. Primary production increased in Suisun Bay (Table 2) as $\mathrm{NH}_{4}$ concentrations declined (Fig. 5C and D) and both 
Table 2

Chlorophyll concentrations and carbon uptake (mean \pm SD) in Sacramento River and SF Estuary by river region (number of stations) for March and April 2009.

\begin{tabular}{|c|c|c|c|c|c|c|c|}
\hline River Region & $\begin{array}{l}\text { Chl-a in cells } \\
>0.7-\mu \mathrm{m}\left(\mu \mathrm{g} \mathrm{L}^{-1}\right)\end{array}$ & $\begin{array}{l}\text { Chl-a in cells } \\
>5.0-\mu \mathrm{m}\left(\mu \mathrm{g} \mathrm{L}^{-1}\right)\end{array}$ & $\begin{array}{l}\% \text { Chl-a in cells } \\
>5.0-\mu \mathrm{m}\left(\mu \mathrm{g} \mathrm{L}^{-1}\right)\end{array}$ & $\rho C\left(\mu \mathrm{mol} \mathrm{L}^{-1} \mathrm{~d}^{-1}\right)$ & $\begin{array}{l}\text { Assimilation.Number } \\
\left(\mu \mathrm{mol} \mathrm{L}{ }^{-1} \mathrm{~d}^{-1}(\mu \mathrm{g} \text { chl-a })^{-1}\right)\end{array}$ & $\begin{array}{l}\rho C \text { as } \% \text { of } \\
\text { Upper River (\%) }\end{array}$ & $\mathrm{VC}\left(\mathrm{d}^{-1}\right)$ \\
\hline \multicolumn{8}{|l|}{ March 2009} \\
\hline Upper River (4) & $4.6 \pm 0.6$ & $3.8 \pm 0.4$ & 83 & $14.13 \pm 1.34$ & 3.07 & & $0.15 \pm 0.03$ \\
\hline SRWTP (3) & $2.4 \pm 0.6$ & $1.8 \pm 0.5$ & 75 & $8.47 \pm 1.77$ & 3.53 & 60 & $0.08 \pm 0.02$ \\
\hline Central River (3) & $1.4 \pm 0.2$ & $1.1 \pm 0.2$ & 79 & $5.38 \pm 0.59$ & 3.87 & 38 & $0.06 \pm 0.00$ \\
\hline Lower River (4) & $1.9 \pm 0.3$ & $1.1 \pm 0.1$ & 58 & $4.47 \pm 1.30$ & 2.35 & 32 & $0.03 \pm 0.06$ \\
\hline Suisun Bay (6) & $2.7 \pm 0.3$ & $1.2 \pm 0.3$ & 44 & $9.39 \pm 1.26$ & 3.47 & 64 & $0.05 \pm 0.01$ \\
\hline San Pablo Bay (1) & 4.6 & 1.8 & 39 & 24.11 & 5.24 & 171 & 0.29 \\
\hline \multicolumn{8}{|l|}{ April 2009} \\
\hline Upper River (4) & $6.4 \pm 1.7$ & $4.5 \pm 1.3$ & 70 & $36.32 \pm 8.50$ & 5.68 & & $0.31 \pm 0.07$ \\
\hline SRWTP (3) & $3.2 \pm 0.4$ & $2.3 \pm 0.3$ & 72 & $18.02 \pm 4.62$ & 5.63 & 50 & $0.13 \pm 0.04$ \\
\hline Central River (3) & $1.9 \pm 0.5$ & $3.4 \pm 0.4$ & 69 & $11.01 \pm 1.52$ & 5.79 & 30 & $0.11 \pm 0.00$ \\
\hline Lower River (4) & $4.5 \pm 1.5$ & $2.9 \pm 1.2$ & 64 & $13.66 \pm 3.58$ & 3.03 & 38 & $0.08 \pm 0.02$ \\
\hline Suisun Bay (6) & $6.1 \pm 3.0$ & $4.4 \pm 2.2$ & 72 & $21.59 \pm 9.19$ & 3.50 & 59 & $0.09 \pm 0.03$ \\
\hline San Pablo Bay (1) & 9.0 & 4.5 & 50 & 36.07 & 4.00 & 99 & 0.30 \\
\hline
\end{tabular}

phytoplankton $\mathrm{NO}_{3}$ and $\mathrm{NH}_{4}$ uptake also increased (Table 3 and Fig. 5A, B). Primary production was highest in San Pablo Bay (24.11 and $36.07 \mu \mathrm{mol} \mathrm{C} \mathrm{L}^{-1} \mathrm{~d}^{-1}$ for March and April, respectively) relative to other locations along the survey (Table 2 and Fig. 5A, B). Primary productivity showed a U-shaped pattern with peaks at each end of the transect. Nitrogen uptake showed the same downstream U-shaped pattern with peak $\mathrm{NO}_{3}$ uptake rates in the Upper River and San Pablo Bay (Table 3 and Fig. 5A, B).

Additional insight into the underlying physiological mechanisms of the phytoplankton can be obtained from the biomass-specific C and N uptake rates (VC or VN) from the Upper River region to San Pablo Bay (Fig. 5C and D). Unlike $\rho C$ and $\rho N$, VC and VN do not reflect any changes in biomass as seen with chlorophyll-a along the surveys but indicate physiological changes. Still, similar U-shaped patterns, consistent with that observed for chlorophylla concentrations and phytoplankton $\mathrm{C}$ and $\mathrm{N}$ uptake rates $(\rho \mathrm{C}$ and $\rho \mathrm{N}$ ), were observed for $\mathrm{VC}$ and $\mathrm{VN}$. This U-shape was an inverse pattern to that of $\mathrm{NH}_{4}$ concentration. The transition from a $\mathrm{NO}_{3}$ uptake-based phytoplankton population to one based on $\mathrm{NH}_{4}$ uptake is seen in the progression from Upper River to the SRWTP region. In the Upper River region, high $\mathrm{VNO}_{3}$ of $0.3 \mathrm{~d}^{-1} \mathrm{im}-$ plies a doubling time of the phytoplankton population of about 3 days, based on $\mathrm{NO}_{3}$ uptake. At the SRWTP region, $\mathrm{VNO}_{3}$ decreased dramatically to near-detection limits and $\mathrm{VNH}_{4}$ increased, accompanying increased $\mathrm{NH}_{4}$ concentration. $\mathrm{VNH}_{4}$ then declined downstream as $\mathrm{NH}_{4}$ concentrations increased further. From the Lower River region to Suisun Bay, $\mathrm{VNO}_{3}$ remained low and unchanged, and $\mathrm{VNH}_{4}$ was either unchanged (March) or increased (April). Peak specific carbon uptake (VC) coincided with peak $\mathrm{VNO}_{3}$ in the Upper River region and in San Pablo Bay where $\mathrm{NH}_{4}$ concentrations were lowest. Within the Sacramento River downstream of the Upper River region, VC rates declined, reaching near zero in the Lower River during March, paralleling the decrease in $\mathrm{VNH}_{4}$.

The elevated $\mathrm{NH}_{4}$ concentrations introduced in the SRWTP region were related negatively to both phytoplankton $\mathrm{NO}_{3}$ and $\mathrm{NH}_{4}$ uptake (Fig. 6A and B). Biomass-specific $\mathrm{NO}_{3}$ uptake decreased exponentially with increasing $\mathrm{NH}_{4}$ concentrations, starting at $<2 \mu \mathrm{mol} \mathrm{NH} \mathrm{L}_{4}^{-1}$ (Fig. 6A). Biomass-specific $\mathrm{NH}_{4}$ uptake versus $\mathrm{NH}_{4}$ concentration showed a complex pattern with indications of inhibition of $\mathrm{VNH}_{4}$ at both low and high $\mathrm{NH}_{4}$ concentrations (Fig. 6B). Within the SRWTP and Central River regions where effluent is first introduced to the Sacramento River, linear regression analysis shows $\mathrm{VNH}_{4}$ was negatively correlated with $\mathrm{NH}_{4}$ concentration for both transects, with nearly identical regression slopes $(-0.0031$ and -0.0039$)$ and high $r^{2}$ values, indicating that effluent $\mathrm{NH}_{4}$ decreased $\mathrm{NH}_{4}$ uptake (Fig. 6B). At other locations within the river, there was no correlation between $\mathrm{VNH}_{4}$ and $\mathrm{NH}_{4}$ concentration.
Estimates of depth-integrated phytoplankton $\mathrm{NH}_{4}$ uptake (4.65 mmol $\mathrm{NH}_{4} \mathrm{~m}^{-2} \mathrm{~d}^{-1}$ ) and water column $\mathrm{NH}_{4}$ concentration $\left(288.16 \mathrm{mmol} \mathrm{N} \mathrm{m}^{-2}\right)$ in the SRWTP region were calculated for April 2009 using the mean surface $\mathrm{\rho NH}_{4}$ uptake of $1.41 \mu \mathrm{mol} \mathrm{N} \mathrm{L}^{-1} \mathrm{~d}^{-1}$; Table 3 ) multiplied by a euphotic zone depth of $3.3 \mathrm{~m}$ and the mean surface $\mathrm{NH}_{4}$ concentration of $36.02 \mu \mathrm{mol} \mathrm{N} \mathrm{L}{ }^{-1}$ multiplied by $8 \mathrm{~m}$ (the depth at RM44). The proportion of the water column $\mathrm{NH}_{4}$ taken up by the phytoplankton was then estimated to be $4.65 \mathrm{mmol} \mathrm{N} \mathrm{m} \mathrm{N}^{-2} \mathrm{~d}^{-1} / 288.16 \mathrm{mmol} \mathrm{N} \mathrm{m}^{-2}=0.016 \mathrm{~d}^{-1}$ or $1.6 \%$ of the water column $\mathrm{NH}_{4}$ each day. A river nitrification rate, estimated using the mass balance approach for increasing $\mathrm{NO}_{3}$ downstream, was $4.0 \mu \mathrm{mol} \mathrm{N} \mathrm{L} \mathrm{N}^{-1} \mathrm{~d}^{-1}$. Using the average specific nitrification factor, nitrification was estimated to be $6.4 \mu \mathrm{mol} \mathrm{N} \mathrm{L}{ }^{-1} \mathrm{~d}^{-1}$. Assuming a fully mixed water column of $8 \mathrm{~m}$ depth translates to a depth integrated rate of $32.0-51.2 \mathrm{mmol} \mathrm{N} \mathrm{m}^{-2} \mathrm{~d}^{-1}$.

\section{Discussion}

\subsection{Depressed primary production in the Sacramento River}

The Sacramento River has been thought to be a source of organic carbon to the Northern SFE (Jassby et al., 2002; Sobczak et al., 2005; Lehman et al., 2008). However the data reported here, similar to the limited primary production estimates for the main channel provided by Lehman et al. (2008), indicate that primary production and phytoplankton biomass in the Sacramento River in spring are actually lower than rates and stocks found in the Northern SFE (including in the well-described low productivity region of Suisun Bay, e.g. Kimmerer, 2005; Wilkerson et al., 2006).

Primary production in the Upper River region was relatively high (equivalent to $<70 \%$ to ca. $100 \%$ of the rates measured in San Pablo Bay) but was strongly depressed in the middle section of the river. At the SRWTP region, primary production decreased by more than $50 \%$ compared to the Upper River region. Primary production in the Central River and Lower River regions were the most strongly depressed but began to increase again through Suisun Bay. This generalized U-shaped downstream spatial pattern of primary production was consistent between the two surveys. Clearly, the river is not a significant source of phytoplankton derived organic carbon to Suisun Bay as both primary productivity and chlorophyll-a concentrations are higher in Suisun Bay than in the inflowing river water. These results are in stark contrast to historic phytoplankton surveys of the Sacramento River made during the 1960's when phytoplankton stocks gradually increased moving downstream with highest abundances found at Isleton (ISL). At that time the phytoplankton community in the river was dominated by diatoms (Greenberg, 1964). While phytoplankton 
A

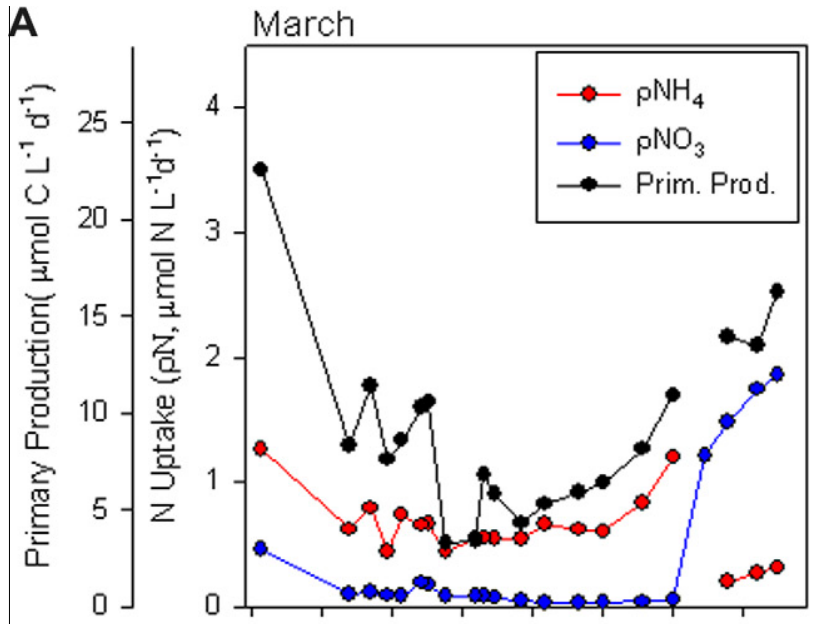

B

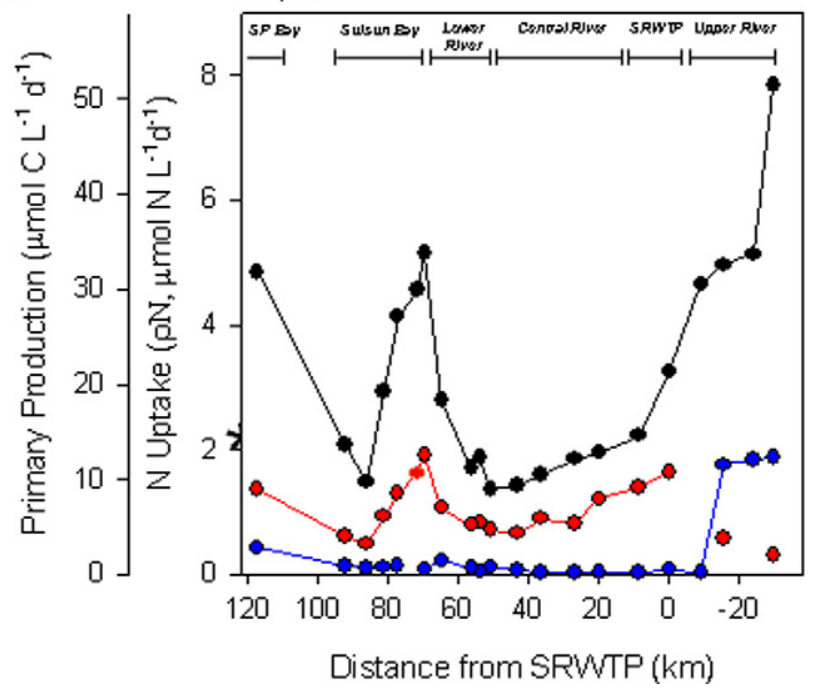

C March

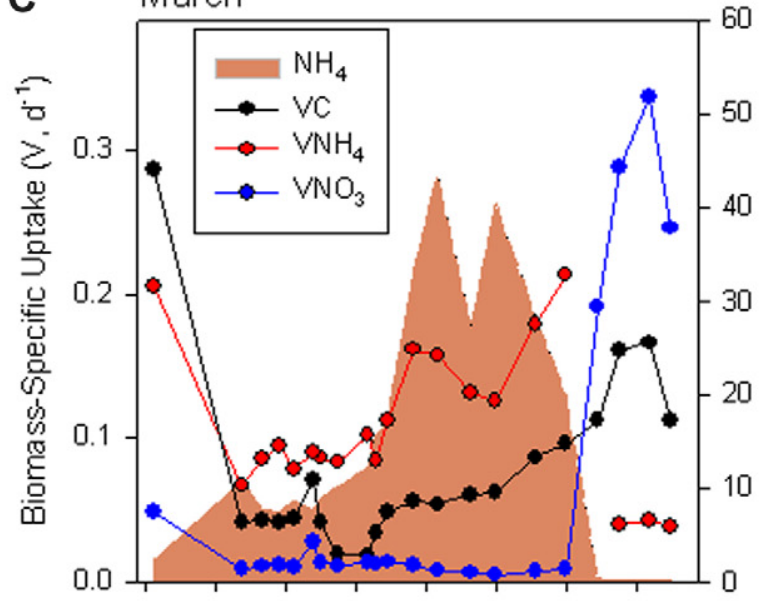

D April

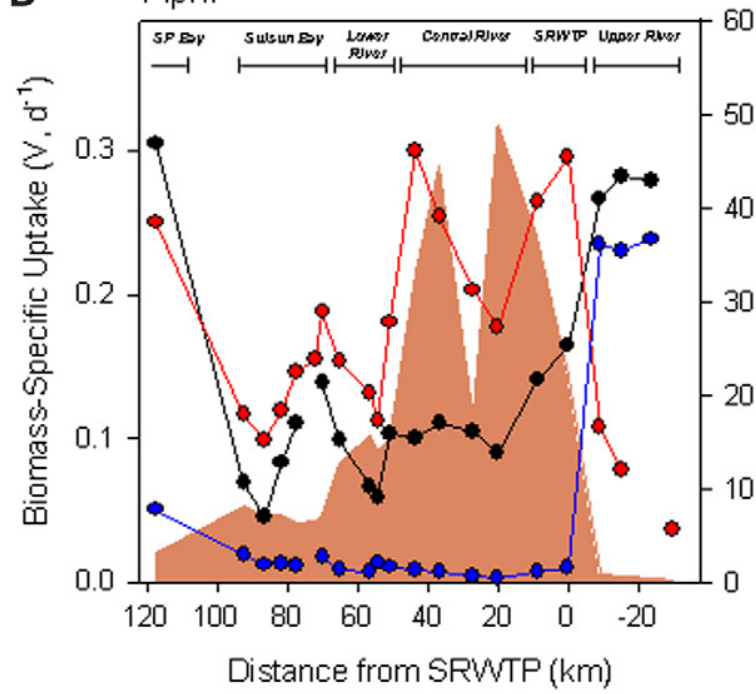

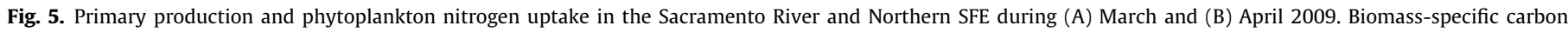

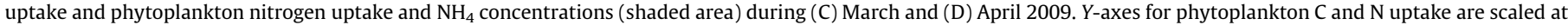
$6.6 \mathrm{C}: 1 \mathrm{~N}$ (i.e. the Redfield ratio).

Table 3

Ammonium and nitrate uptake (mean \pm SD) in Sacramento River and SF Estuary by river region (number of stations) for March and April 2009.

\begin{tabular}{|c|c|c|c|c|c|}
\hline \multirow[t]{2}{*}{ River Region } & $\rho \mathrm{NH}_{4}$ & $\mathrm{\rho NO}_{3}$ & \multirow[t]{2}{*}{$\% \mathrm{NO}_{3}$ uptake $\%$} & \multirow{2}{*}{$\begin{array}{l}\mathrm{VNH}_{4} \\
\mathrm{~d}^{-1} \\
\end{array}$} & \multirow[t]{2}{*}{$\mathrm{VNO}_{3}$} \\
\hline & \multicolumn{2}{|c|}{$\mu \mathrm{mol} \mathrm{N} \mathrm{L}{ }^{-1} \mathrm{~d}^{-1}$} & & & \\
\hline \multicolumn{6}{|l|}{ March 2009} \\
\hline Upper River (4) & $0.26 \pm 0.06$ & $1.57 \pm 0.29$ & 86 & $0.04 \pm 0.00$ & $0.27 \pm 0.06$ \\
\hline SRWTP (3) & $0.88 \pm 0.30$ & $0.04 \pm 0.01$ & 4 & $0.18 \pm 0.05$ & $0.01 \pm 0.00$ \\
\hline Central River (3) & $0.61 \pm 0.06$ & $0.04 \pm 0.01$ & 6 & $0.15 \pm 0.02$ & $0.01 \pm 0.00$ \\
\hline Lower River (4) & $0.50 \pm 0.08$ & $0.08 \pm 0.04$ & 14 & $0.10 \pm 0.02$ & $0.01 \pm 0.00$ \\
\hline Suisun Bay (6) & $0.65 \pm 0.13$ & $0.12 \pm 0.05$ & 16 & $0.11 \pm 0.05$ & $0.01 \pm 0.01$ \\
\hline San Pablo Bay (1) & 1.26 & 0.46 & 27 & 0.21 & 0.05 \\
\hline \multicolumn{6}{|l|}{ April 2009} \\
\hline Upper River (4) & $0.44 \pm 0.19$ & $1.82 \pm 0.05$ & 81 & $0.06 \pm 0.03$ & $0.23 \pm 0.00$ \\
\hline SRWTP (3) & $1.41 \pm 0.21$ & $0.06 \pm 0.03$ & 4 & $0.25 \pm 0.06$ & $0.01 \pm 0.00$ \\
\hline Central River (3) & $0.80 \pm 0.12$ & $0.03 \pm 0.01$ & 4 & $0.25 \pm 0.05$ & $0.01 \pm 0.00$ \\
\hline Lower River (4) & $0.86 \pm 0.15$ & $0.08 \pm 0.03$ & 9 & $0.14 \pm 0.03$ & $0.01 \pm 0.00$ \\
\hline Suisun Bay (6) & $1.15 \pm 0.56$ & $0.14 \pm 0.05$ & 11 & $0.14 \pm 0.03$ & $0.02 \pm 0.00$ \\
\hline San Pablo Bay (1) & 1.36 & 0.43 & 24 & 0.25 & 0.05 \\
\hline
\end{tabular}

species were not enumerated during this study, the same stations were occupied during spring 2010 and showed a mixed phytoplankton community in the upper river (with diatoms comprising $\sim 40 \%$ of the cells) to a community dominated ( $~ 80 \%)$ by small flagellates and green algae below the SRWTP region (Kress, personal communication) and with diatoms in Suisun and San Pablo Bays (Dugdale et al., submitted for publication).

Because light attenuation is largely explained by turbidity, the potential role that turbidity plays in the present results can be explored using euphotic zone depth. The ratio of river depth to 

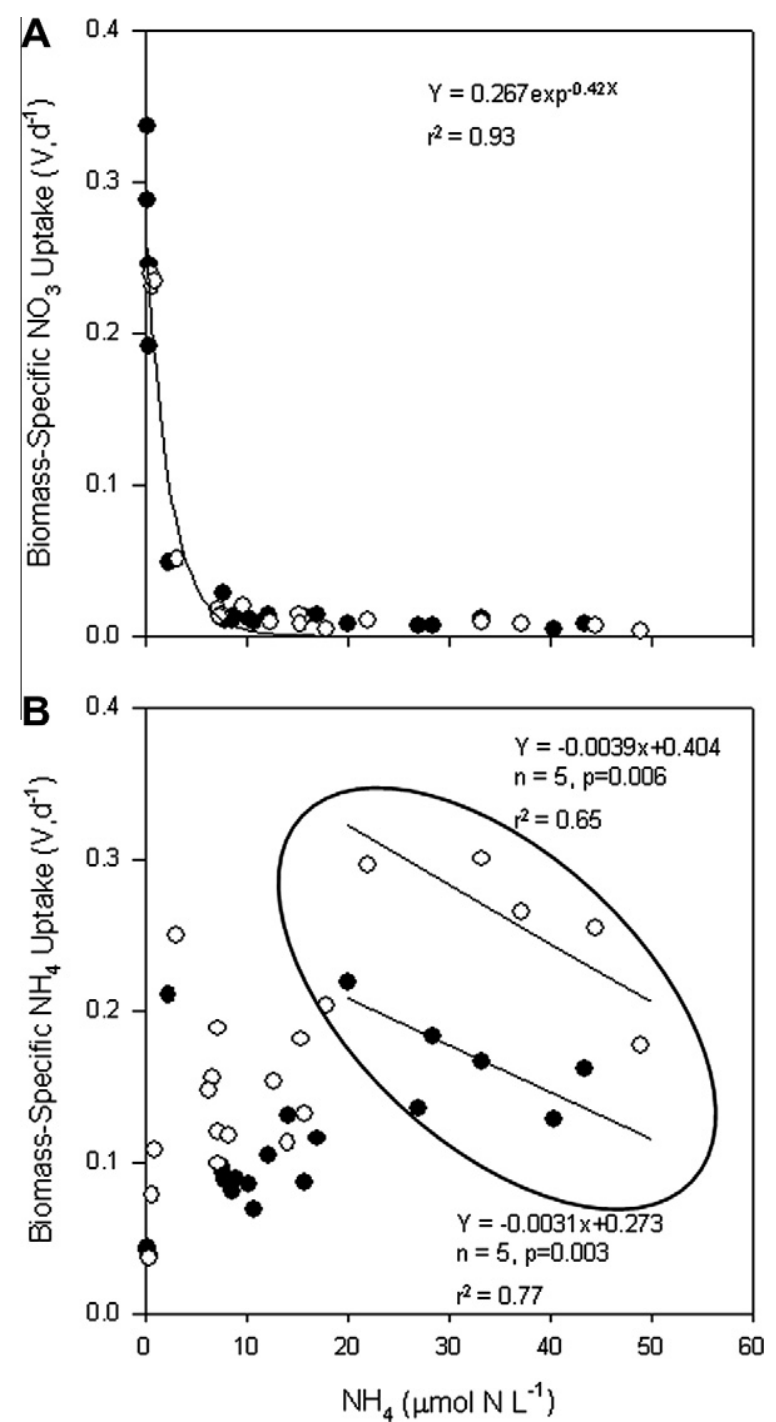

Fig. 6. Effect of $\mathrm{NH}_{4}$ concentration on phytoplankton $\mathrm{N}$ uptake processes in the Sacramento River and Northern Sacramento River. (A) Biomass-specific $\mathrm{NO}_{3}$ uptake rate $\left(\mathrm{VNO}_{3}\right)$ and (B) biomass-specific $\mathrm{NH}_{4}$ uptake rate $\left(\mathrm{VNH}_{4}\right)$ versus $\mathrm{NH}_{4}$ concentrations measured during March (closed circles) and April (open circles) 2009. Linear regression shown in panel B is based on the five stations occupied in the SRWTP and Central River regions (RM44, HOD, KEN, L37, ISL).

euphotic zone depth (i.e. critical depth, Sverdrup, 1953) does not explain chlorophyll-a trends in the Sacramento River. For example, within the Central River region, the photic zone extended to $>70$ $100 \%$ of the river depth (i.e. phytoplankton-received solar energy throughout the water column), yet neither chlorophyll-a or primary production increased there. In contrast, in the eastern end of Suisun Bay water column depth increased significantly (up to $20-\mathrm{m}$ ), increasing the ratio of water depth to euphotic zone. This should result in decreased productivity and chlorophyll-a, yet chlorophyll-a and primary production were higher at these locations compared to shallower regions.

The declining productivity and $\mathrm{NH}_{4}$ uptake conditions in the Sacramento River and Suisun Bay is comparable to observations in other river, estuarine and coastal ecosystems impacted by wastewater effluent (Waiser et al., 2011; Yoshiyama and Sharp, 2006; MacIsaac et al., 1979). In the Delaware Estuary which exhibits a similar range in both primary productivity and $\mathrm{NH}_{4}$ concentrations (Yoshiyama and Sharp, 2006) a decline in the assimilation number (carbon uptake per unit chlorophyll-a) was associated with $\mathrm{NH}_{4}$ concentrations $>10 \mu \mathrm{mol} \mathrm{N} \mathrm{L}{ }^{-1}$ (Yoshiyama and Sharp, 2006). In the Sacramento River, assimilation number declined by 43-47\% from the Upper River to the Lower River and in March mean primary production (Table 2) decreased by a factor of $\sim 3$ from the highest values at the Upper River region to the lowest value in the Lower River region.

\subsection{Effect of $\mathrm{NH}_{4}$ on river primary production and nutrient uptake}

The U-shaped spatial pattern of chlorophyll-a, primary production and phytoplankton $\mathrm{N}$ uptake are the mirror of $\mathrm{NH}_{4}$ concentrations, and appear to be linked to the form of DIN being used by phytoplankton for growth, and by inhibition of $\mathrm{NO}_{3}$ uptake by $\mathrm{NH}_{4}$. The overall pattern that emerges is (1) high productivity at the upper end of the transect, associated with $\mathrm{NO}_{3}$ uptake, (2) a mid-river region (Central River) in which primary production follows $\mathrm{NH}_{4}$ uptake and $\mathrm{NO}_{3}$ uptake is shut-down and $\mathrm{NH}_{4}$ uptake is inhibited (by the high $\mathrm{NH}_{4}$ concentrations), (3) elevated productivity in Suisun Bay and San Pablo Bay where both $\mathrm{NO}_{3}$ and $\mathrm{NH}_{4}$ fuel productivity.

This pattern and its relation to ambient $\mathrm{NH}_{4}$ are better visualized in plots (Fig. 7A-F) of mean uptake rates for the different transect regions (Tables 2 and 3 ) versus mean $\mathrm{NH}_{4}$ concentration (Table 1 ). The patterns for $\mathrm{\rho NO}_{3}$ versus $\mathrm{NH}_{4}$ for March and April transects (Fig. 7A) are similar with an immediate decline in uptake from the relatively high levels in the Upper River to very low levels at the SRWTP and the Central River as $\mathrm{NH}_{4}$ concentrations increase to $30-35 \mu \mathrm{mol} \mathrm{N} \mathrm{L}{ }^{-1} \cdot \mathrm{\rho NO}_{3}$ remains low in Lower River as $\mathrm{NH}_{4}$ concentrations decrease and then increases in Suisun Bay and San Pablo Bay with further decreases in $\mathrm{NH}_{4}$. When $\mathrm{NO}_{3}$ uptake is normalized to the mean Upper River value for March (Fig. 7B), the patterns are virtually identical for the two transects sampled one month apart. The progression of $\mathrm{\rho NH}_{4}$ (Fig. 7C) shows an opposite pattern to $\mathrm{\rho NO}_{3}$ uptake, initially low in the Upper River at low $\mathrm{NH}_{4}$ concentration, increasing to a peak at SRWTP with effluent $\mathrm{NH}_{4}$ input, decreasing to Central River and Lower River, and finally increasing at Suisun Bay and San Pablo Bay at the lowest $\mathrm{NH}_{4}$ concentration. The pattern is similar for March and April, especially apparent when normalized to mean Upper River $\rho \mathrm{NH}_{4}$ values for March (Fig. 7D). Carbon uptake, $\rho C$ (based upon the combined uptake of $\mathrm{NH}_{4}$ and $\mathrm{NO}_{3}$ ) when plotted against $\mathrm{NH}_{4}$ concentration (Fig. 7E), decreases 50-60\% from the Upper River to the SRWTP region with high effluent $\mathrm{NH}_{4}$ (Table 2). A further decrease (to 30-38\% of Upper River values) occurs in the Central River with increased $\mathrm{NH}_{4}$. Carbon uptake remains low in the Lower River as $\mathrm{NH}_{4}$ declines. Finally, $\rho \mathrm{C}$ increases in Suisun Bay to 59-64\% of the Upper River carbon uptake as $\mathrm{NH}_{4}$ declines further (Fig. 7E) and $\mathrm{NO}_{3}$ uptake begins to increase (Fig. 7A). The normalized plot for $\rho \mathrm{C}$ versus $\mathrm{NH}_{4}$ shows that the patterns for March and April are almost identical (Fig. 7F). The result is little assimilatory capacity of the river DIN by the phytoplankton and flux of $\mathrm{NH}_{4}$ and $\mathrm{NO}_{3}$ and little organic carbon to the Northern estuary.

Diminished estuarine productivity and the lack of spring phytoplankton blooms in Suisun Bay was attributed to the inability of the phytoplankton to access the largest inorganic $\mathrm{N}$ pool that was $\mathrm{NO}_{3}$, due to $\mathrm{NH}_{4}$ inhibition (Wilkerson et al., 2006; Dugdale et al., 2007). This apparently occurred also in the Sacramento River (Fig. 5) where there was high primary production at low $\mathrm{NH}_{4}$ concentrations and phytoplankton $\mathrm{N}$ demand was satisfied by $\mathrm{NO}_{3}$. Although phytoplankton use $\mathrm{NH}_{4}$ before $\mathrm{NO}_{3}$, sometimes referred to as a "preference" for $\mathrm{NH}_{4}$ (McCarthy et al., 1977), some diatoms require $\mathrm{NO}_{3}$ over $\mathrm{NH}_{4}$ under some conditions (Glibert et al., 2004, 2006). Reduced primary production was associated with high $\mathrm{NH}_{4}$ concentrations and the inhibition of phytoplankton $\mathrm{NO}_{3}$ uptake. The decrease in phytoplankton $\mathrm{NO}_{3}$ uptake with increasing river $\mathrm{NH}_{4}$ concentration is consistent with many previous studies 
A

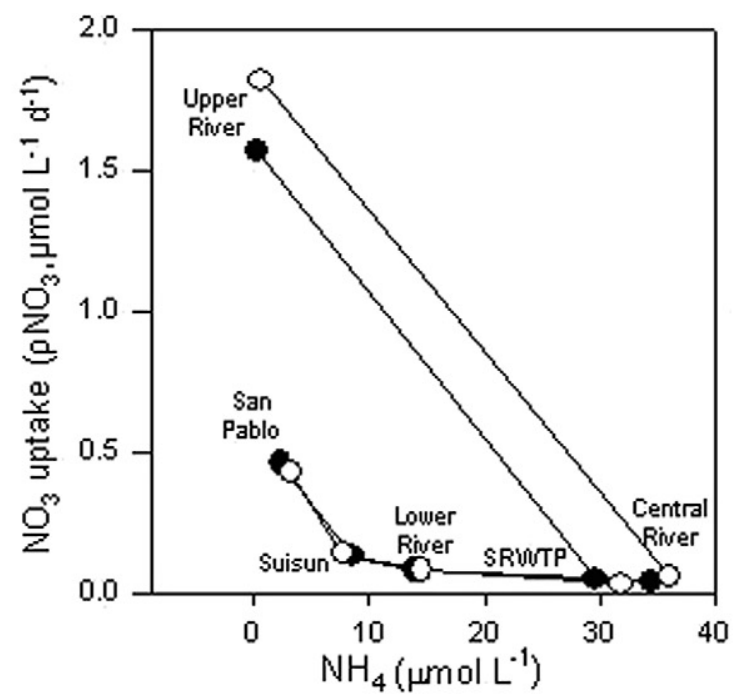

C

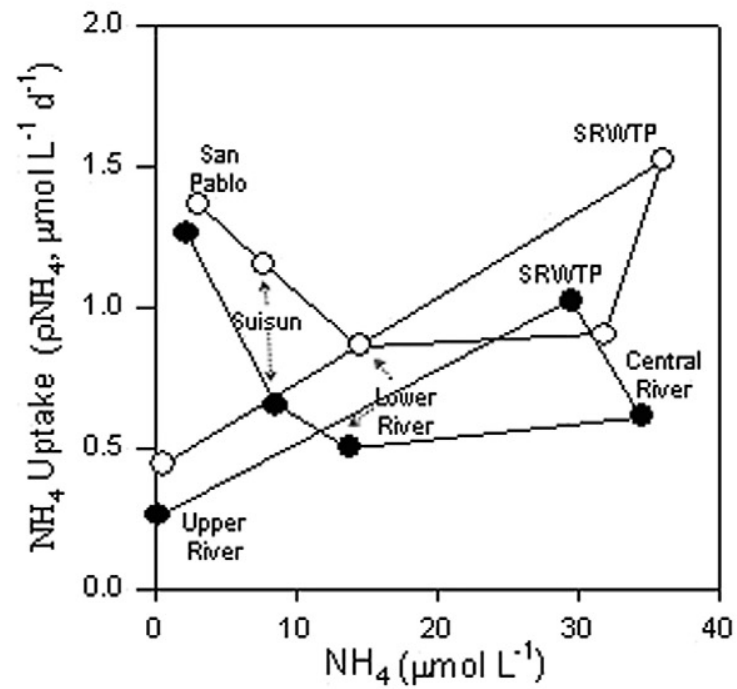

E

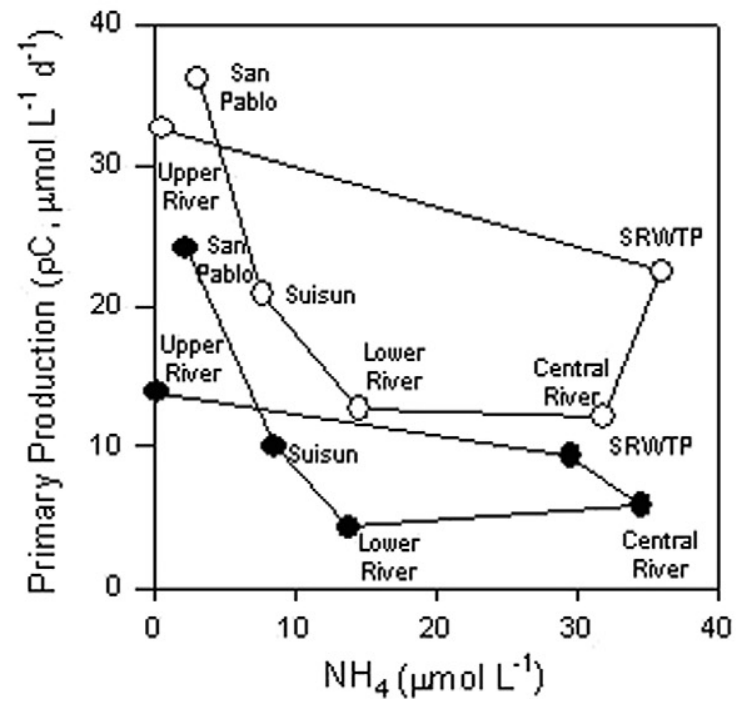

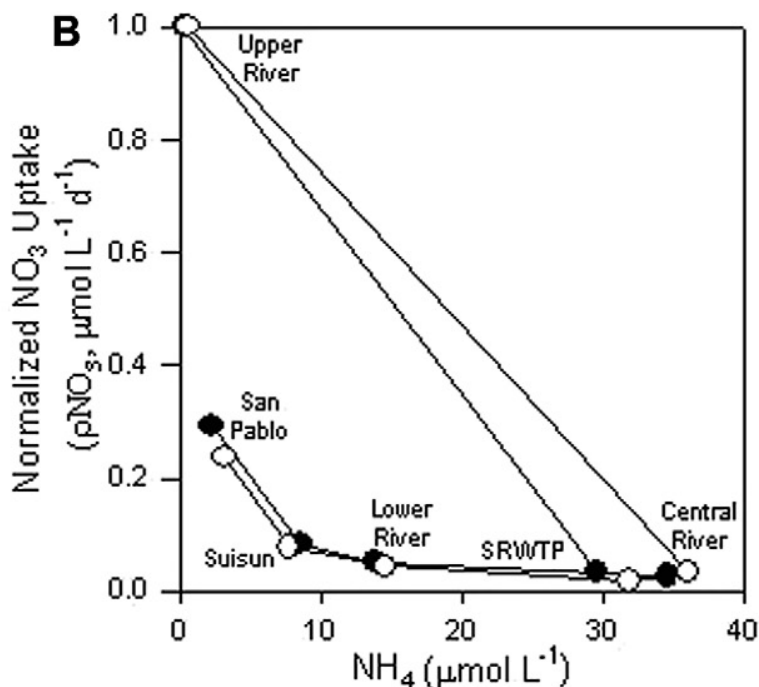
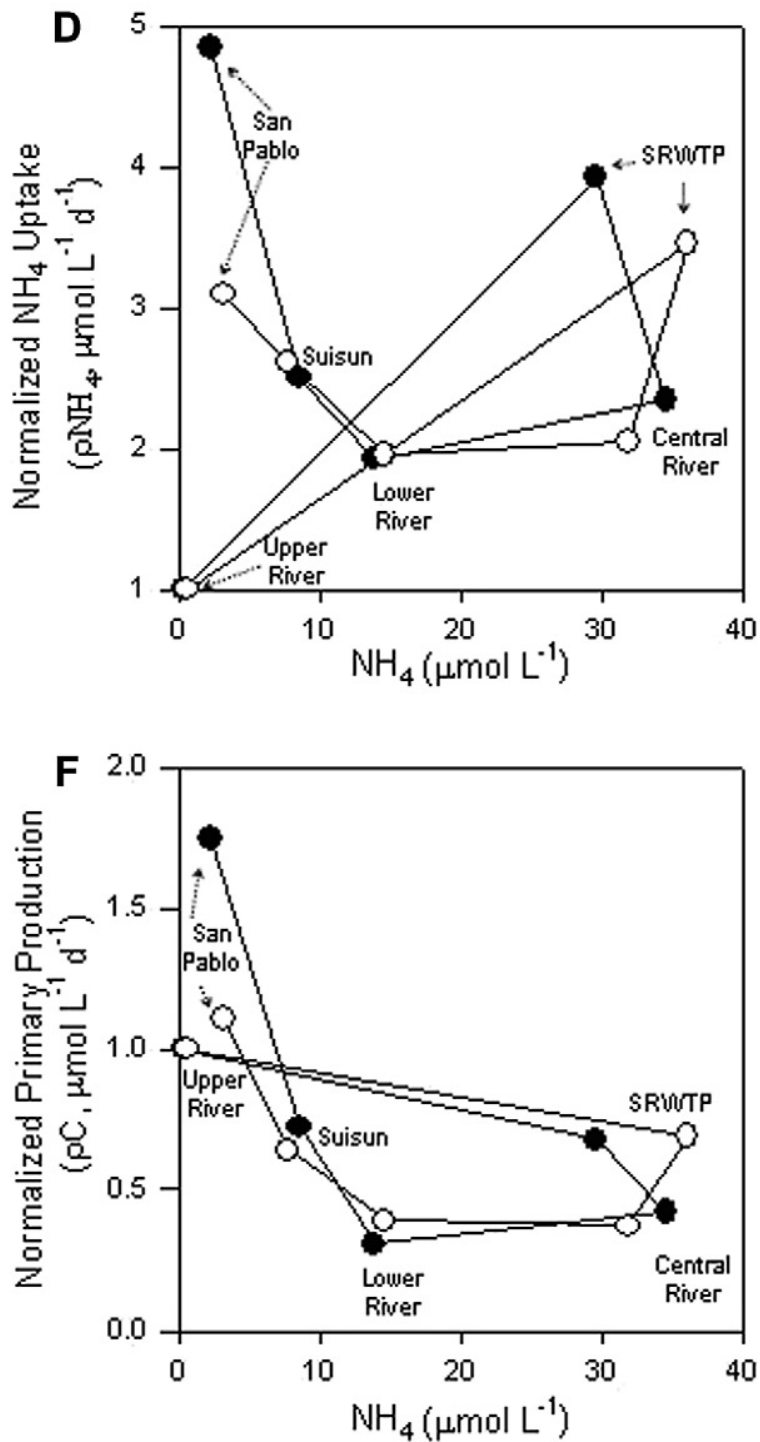

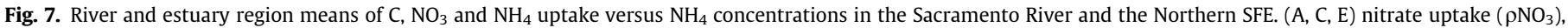
ammonium uptake $\left(\rho \mathrm{NH}_{4}\right)$, and carbon uptake $(\rho \mathrm{C})$. (B, D, F) The same data with uptake rates normalized to Upper River region mean uptake ( $\rho$ ) rates. 
(Dortch, 1990), including those made in the SFE (Dugdale et al., 2007), Hong Kong waters (e.g. Xu et al., 2011) and coastal waters (Dugdale et al., 2006). An exponential function is often used to describe the inhibition of $\mathrm{NO}_{3}$ uptake by $\mathrm{NH}_{4}$ (e.g. Cochlan and Harrison, 1991) and this approach fit the data well here suggesting that $\mathrm{NH}_{4}$ is the major factor in the reduced $\mathrm{NO}_{3}$ uptake (Fig. 6A).

Another contribution to the depression in primary production and the decrease in chlorophyll-a in the river may be $\mathrm{NH}_{4}$ inhibition of phytoplankton $\mathrm{NH}_{4}$ uptake (Syrett, 1981). Suppression of $\mathrm{VNH}_{4}$ immediately downstream of the SRWTP discharge was related to increased $\mathrm{NH}_{4}$ concentrations (Fig. 6B). Two situations apparently exist within the Sacramento River. In the SRWTP and Central River regions where wastewater $\mathrm{NH}_{4}$ discharge is most pronounced, phytoplankton $\mathrm{NH}_{4}$ uptake is negatively correlated with $\mathrm{NH}_{4}$ concentration. At other locations this does not occur. We are aware of at least one study that showed inhibition of both phytoplankton $\mathrm{NH}_{4}$ uptake and primary production with additions of sewage effluent containing primarily $\mathrm{NH}_{4}$ (Maclsaac et al., 1979). It is unclear in the present study whether $\mathrm{NH}_{4}$ or some other component of the sewage effluent (of which $\mathrm{NH}_{4}$ concentrations act as a "tracer") is responsible for the relationship observed here between $\mathrm{VNH}_{4}$ and $\mathrm{NH}_{4}$ concentrations although experimental additions of SRWTP effluent into Sacramento River water collected upstream of SRWTP influence showed the same result (Parker et al., 2009). The combination of these effects and resultant depression in primary production result in unused nutrients passing downstream of the Sacramento River and into Suisun Bay.

\subsection{Effect of phytoplankton assimilation and nitrification on Sacramento River $\mathrm{NH}_{4}$ concentrations}

The extent to which phytoplankton $\mathrm{NH}_{4}$ assimilation contributes to the decline in $\mathrm{NH}_{4}$ concentrations downstream from the SRWTP can be estimated, as can microbial transformations such as nitrification (ammonia oxidation). With a river transport time of about 4 days from the SRWTP to the entrance of Suisun Bay, phytoplankton $\mathrm{NH}_{4}$ uptake would account for only $6 \%$ of the water column $\mathrm{NH}_{4}$ concentrations found in the SRWTP region. Based on this analysis, using a maximal estimate of the vertically integrated $\mathrm{NH}_{4}$ uptake, phytoplankton have only a negligible influence on river $\mathrm{NH}_{4}$ concentration as it flows downstream.

An additional, potentially important sink for anthropogenic $\mathrm{NH}_{4}$ entering the Sacramento River is nitrification. This is the sequential oxidization of $\mathrm{NH}_{4}$ to $\mathrm{NO}_{2}$ and $\mathrm{NO}_{3}$ to support chemosynthesis and is carried out in estuaries by $\mathrm{NH}_{4}$-oxidizing bacteria and some archaea (e.g. AOA, Francis et al., 2005; Caffrey et al., 2007). Hager and Schemel (1992) showed that increases in $\mathrm{NO}_{3}$ were correlated with decreases in $\mathrm{NH}_{4}$ in the Sacramento River and inferred that nitrification might be a cause. A similar pattern was observed during this study, with elevated $\mathrm{NH}_{4}$ at the SRWTP region that decreased, while $\mathrm{NO}_{3}$ increased toward Suisun Bay. In the region where there was the greatest decrease in $\mathrm{NH}_{4}$ and increase in $\mathrm{NO}_{3}$, the intermediate inorganic $\mathrm{N}$ form, $\mathrm{NO}_{2}$ was observed also suggesting that nitrification was occurring (Fig. $4 \mathrm{~A}$ and $\mathrm{B}$ ). Dark incubations using water collected at RM44 showed little conversion of $\mathrm{NH}_{4}$ to $\mathrm{NO}_{3}$ on time scales of seven days but appreciable $\mathrm{NO}_{3}$ increase after 14 days (data not shown); the time lag for conversion of $\mathrm{NH}_{4}$ to $\mathrm{NO}_{3}$ may reflect low initial populations of AOA in the river upstream of the SRWTP region (Pauer and Auer, 2000). Using variation in the natural abundance of ${ }^{15} \mathrm{~N}$ in $\mathrm{NO}_{3}$ and $\mathrm{NH}_{4}$, Kendall observed declining $\delta^{15} \mathrm{~N}-\mathrm{NO}_{3}$ and increasing $\delta^{15} \mathrm{~N}-\mathrm{NH}_{4}$; in the river below the SRWTP; evidence of nitrification with indications of strong nitrification in the vicinity of US657 (Kendall, personal communication).

Our two estimates of Sacramento River nitrification rates give a range (4.0-6.4 $\mu \mathrm{mol} \mathrm{N} \mathrm{L}^{-1} \mathrm{~d}^{-1}$ ) comparable to other eutrophic systems that translates to a depth integrated rate of 32 -
$51.2 \mathrm{mmol} \mathrm{N} \mathrm{m}^{-2} \mathrm{~d}^{-1}$ assuming a fully mixed water column of 8 m depth. Lipschultz et al. (1986) estimated July-September nitrification in the highly eutrophic region of the Delaware River of 0.08-0.47 $\mu \mathrm{mol} \mathrm{N} \mathrm{L}^{-1} \mathrm{~h}^{-1}$ (or 1.9-11 $\mu \mathrm{mol} \mathrm{N} \mathrm{L}^{-1} \mathrm{~d}^{-1}$ ). Feliatra and Bianchi (1993) measured nitrification rates of 0.23 $2.15 \mu \mathrm{mol} \mathrm{N} \mathrm{L} \mathrm{L}^{-1} \mathrm{~d}^{-1}$ in the Rhone River where $\mathrm{NH}_{4}$ concentrations varied between 1 and $10 \mu \mathrm{mol} \mathrm{N} \mathrm{L}{ }^{-1}$. While the present estimates of nitrification for the Sacramento River are crude, the measured water column $\mathrm{NH}_{4}$ uptake rate by phytoplankton is $9.1-14.5 \%$ of the inferred nitrification rate, indicating that nitrification may be the more significant biological process affecting the fate of $\mathrm{NH}_{4}$ in the Sacramento River. Direct measurements of water column nitrification for the Sacramento River are needed.

Both nitrification and phytoplankton $\mathrm{N}$ uptake processes influence the concentrations of $\mathrm{NH}_{4}$ downstream in the river. However, the sum of the two processes, at most $8 \mu \mathrm{mol} \mathrm{N} \mathrm{L} \mathrm{L}^{-1} \mathrm{~d}^{-1}$, are insufficient to prevent the export of substantial effluent-derived $\mathrm{NH}_{4}$ to Suisun Bay and other seaward embayments of the Northern SFE. The $\mathrm{NH}_{4}$ resulting from SRWTP effluent combined with phytoplankton nutrient assimilation and potential nitrification results in a mirror pattern of $\mathrm{NH}_{4}$ concentration to the downstream Ushaped pattern of phytoplankton uptake and productivity. The delivery of $\mathrm{NH}_{4}$ to the Northern SFE potentially impacts the pelagic food web and the success of pelagic fishes in this ecosystem.

\section{Conclusions}

Wastewater discharge from the Sacramento Regional Wastewater Treatment Plant fundamentally changes the microbial processes and biogeochemistry of the river as well as the receiving waters of the San Francisco Estuary and Delta. This study shows the importance of the effluent $\mathrm{NH}_{4}$ contribution to the DIN pool used by river and estuarine phytoplankton. Three observations have been identified that show how wastewater discharge has changed the chemistry and biology of the river: (1) The secondary-level treatment in the wastewater results in substantial $\mathrm{NH}_{4}$ concentrations in the Sacramento River downstream of the sewage discharge point. (2) Elevated $\mathrm{NH}_{4}$ concentrations prevent access by the phytoplankton to high concentrations of $\mathrm{NO}_{3}$ by inhibiting uptake, suppressing $\mathrm{NH}_{4}$ uptake and depressing primary production downstream to Suisun Bay. (3) Phytoplankton $\mathrm{NH}_{4}$ uptake rates and nitrification rates within the Sacramento River are insufficient to appreciably reduce $\mathrm{NH}_{4}$ concentrations within the river, resulting in significant $\mathrm{NH}_{4}$ loading to the Northern SFE, suppressing phytoplankton blooms and high primary productivity there. These results indicate that control of river nutrients, especially $\mathrm{NH}_{4}$ loading, is essential to management efforts to restore the river/estuary to a productive condition.

\section{Acknowledgments}

We wish to thank C. Foe and the staff of the California Central Valley Regional Water Quality Control Board and C. Irvine and the Sacramento Regional Sanitation District for assistance with station selection and sampling design. We wish to thank A. Marchi, J. Davidson-Drexel, J. Fuller, and S. Blaser for laboratory analysis and the crew of the $R / V$ Questuary for technical assistance and field support. E. Kress provided helpful information about phytoplankton community composition in the Sacramento River. This research was funded by the Federal and California State Water Contractors and the San Luis and Delta-Mendota Water Authority.

\section{References}

Alpine, A., Cloern, J., 1988. Phytoplankton growth rates in a light-limited environment, San Francisco Bay. Marine Ecology Progress Series 44, 167-173. 
Arar, E.J., Collins, G.B., 1992. In vitro determination of chlorophyll a and phaeophytin in marine and freshwater phytoplankton by fluorescence USEPA Method 445.0. USEPA methods for determination of chemical substances in marine and estuarine environmental samples. Cincinnati, $\mathrm{OH}$.

Bennett, W.A., Moyle, P.B., 1996. Where have all the fishes gone? Interactive factors producing fish declines in the Sacramento-San Joaquin Estuary. In: Hollibaugh, J.T. (Ed.), San Francisco Bay: The Ecosystem. Pacific Division of the American Association for the Advancement of Science, San Francisco, pp. 519-542.

Boynton, W.R., Kemp, W.M., Keefe, C.W., 1982. A comparative analysis of nutrient and other factors influencing estuarine phytoplankton production. In: Kennedy, V.S. (Ed.), Estuarine Comparisons. Academic Press, London, pp. 69-90.

Bran and Luebbe Inc., 1999. Silicate in water and seawater. AutoAnalyzer Method No. G-177-96. Bran Luebbe, Inc., Buffalo Grove, IL.

Brooks, M.J., Fleishman, E., Brown, L.R., Lehman, P.W., Werner, I., Scholz, N., Mitchelmore, C., Lovvorn, J.R., Johnson, M.L., Schlenk, D., van Drunick, S., Drever, J.I., Stoms, D.M., Parker, A.E., Dugdale, R.C., 2011. Life Histories, Salinity Zones, and Sublethal Contributions of Contaminants to Pelagic Fish Declines Illustrated with a Case Study of San Francisco Estuary, California, USA. Estuaries and Coasts. doi 10.1007/s12237-011-9459-6.

Caffrey, J.R., Bano, N., Kalanetra, K., Hollibaugh, J.T., 2007. Ammonia oxidation and ammonia-oxidizing bacteria and archaea from estuaries with differing histories of hypoxia. International Society for Microbial Ecology Journal 1, 660-662. doi:10.1038/ismej.2007.79.

Cloern, J.E., 2001. Our evolving conceptual model of the coastal eutrophication problem. Marine Ecology Progress Series 210, 223-253.

Cloern, J.E., Dufford, R., 2005. Phytoplankton community ecology: principles applied in San Francisco Bay. Marine Ecology Progress Series 285, 11-28.

Cochlan, W.P., Bronk, D.A., 2003. Effects of ammonium on nitrate utilization in the Ross Sea, Antarctica: implications for $f$-ratio estimates. In: DiTullio, G.R., Dunbar, R.B. (Eds.), Biogeochemistry of the Ross Sea, Antarctic Research Series, vol. 78. pp. 159-178.

Cochlan, W.P., Harrison, P.J., 1991. Inhibition of nitrate uptake by ammonium and urea in the eukaryotic picoflagellate Micromonus pusilla. Journal of Experimental Marine Biology and Ecology 153, 143-152.

Cole, B.E., Cloern, J.E., 1984. Significance of biomass and light availability to phytoplankton productivity in San Francisco Bay. Marine Ecology Progress Series $17,15-24$.

Collos, Y., Maestrini, S.Y., Robert, J.-M., 1989. High long-term nitrate uptake by oyster-pond microalgae in the presence of high ammonium concentrations. Limnology and Oceanography 34, 957-964.

Dortch, Q., 1990. The interaction between ammonium and nitrate uptake in phytoplankton. Marine Ecology Progress Series 61, 183-201.

Dugdale, R.C., Wilkerson, F.P., Parker, A.E., Marchi, A., Taberski, K. Anthropogenic ammonium impacts spring phytoplankton blooms in the San Francisco Estuary: the cause of blooms in 2000 and 2010. Estuarine and Coastal Shelf Science. Submitted for publication.

Dugdale, R.C., Wilkerson, F.P., Hogue, V.E., Marchi, A., 2007. The role of ammonium and nitrate in spring bloom development in San Francisco Bay. Estuarine, Coastal and Shelf Science 73, 17-29.

Dugdale, R.C., Wilkerson, F.P., Hogue, V., Marchi, A., 2006. Nutrient controls on new production in the Bodega Bay, California, coastal upwelling plume. Deep-Sea Research II 53, 3049-3062.

Dugdale, R.C., Wilkerson, F.P., 1986. The use of $15 \mathrm{~N}$ to measure nitrogen uptake in eutrophic oceans; experimental considerations. Limnology and Oceanography 31, 673-689.

Feliatra, F., Bianchi, M., 1993. Rates of nitrification and carbon uptake in the Rhone River plume (northwestern Mediterranean Sea). Microbial Ecology 26, 21-28.

Francis, C.A., Roberts, K.J., Beman, J.M., Santoro, A.E., Oakley, B.B., 2005. Ubiquity and diversity of ammonia-oxidizing archaea in water columns and sediments of the ocean. Proceedings of the National Academy of Sciences USA 102, 1468314688.

Friederich, G.E., Walz, P.M., Burczriski, M.G., Chavez, F.P., 2002. Inorganic carbon in the central California upwelling system during the 1997-1999 El Niño - La Niña event. Progress in Oceanography 54, 185-203.

Glibert, P.M., 2010. Long-term changes in nutrient loading and stoichiometry and their relationship with changes in the food web and dominant pelagic fish species in the San Francisco Estuary. CA Review in Fisheries Science 18 (2), 211232.

Glibert, P.M., Heil, D., Hollander, M., Revilla, M., Hoare, A., Alexander, J., Murasko, S. 2004. Evidence for dissolved organic nitrogen and phosphorus uptake during a cyanobacterial bloom in Florida Bay. Marine Ecology Progress Series 280, 7383.

Glibert, P.M., Harrison, J., Heil, C.A., Seitzinger, S., 2006. Escalating worldwide use of urea - a global change contributing to coastal eutrophication. Biogeochemistry 77, 441-463.

Glibert, P.M., Fullerton, D., Burkholder, J.M., Cornwell, J., Kana, T.M., 2011. Ecological stoichiometry, biogeochemical cycling, invasive species, and aquatic food webs: San Francisco Estuary and Comparative Systems. Reviews in Fisheries Science 19, 358-417.

Greenberg, A.E., 1964. Plankton in the Sacramento River. Ecology 45, 40-49.

Hager, S.W., Schemel, L.E., 1992. Sources of nitrogen and phosphorus to Northern San-Francisco Bay. Estuaries 15, 40-52.

Holm-Hansen, O., Riemann, B., 1978. Chlorophyll a determination: improvements in methodology. Oikos 30, 438-447.
Jassby, A., 2008. Phytoplankton in the upper San Francisco Estuary: recent biomass trends, their causes and their trophic significance. San Francisco Estuary and Watershed Science 6, 1-24 <http://www.escholarship.org/uc/item/71h077r1>.

Jassby, A.D., Cloern, J.E., Cole, B.E., 2002. Annual primary production: patterns and mechanisms of change in a nutrient-rich tidal ecosystem. Limnology and Oceanography $47,698-712$.

Jassby, A.D., Cole, B.E., Cloern, J.E., 1997. The design of sampling transects for characterizing water quality in estuaries. Estuarine, Coastal, and Shelf Science 45, 285-302.

Kimmerer, W., 2005. Chronic food limitation of egg production in populations on copepods of the genus Acartia in the San Francisco estuary. Estuaries 28, 541 550.

Kimmerer, W., 2006. Long-term changes in apparent uptake of silica in the San Francisco Estuary. Limnology and Oceanography 50, 793-798.

Lehman, P.W., Sommer, T., Rivard, L., 2008. The influence of floodplain habitat on the quantity and quality of riverine phytoplankton carbon produced during the flood season in San Francisco Estuary. Aquatic Ecology 42, 363-378.

L'Helguen, S., Maguer, J.-F., Caradec, J., 2008. Inhibition kinetics of nitrate uptake by ammonium in size-fractionated oceanic phytoplankton communities: implications for new production and $f$-ratio estimates. Journal of Plankton Research 30, 1179-1188.

Lipschultz, F., Wofsey, S.C., Fox, L.E., 1986. Nitrogen metabolism of the eutrophic Delaware River ecosystem. Limnology and Oceanography 31, 701-716.

Legendre, L., Gosselin, M., 1996. Estimation of $\mathrm{N}$ or C uptake rates by phytoplankton using ${ }^{15} \mathrm{~N}$ or ${ }^{13} \mathrm{C}$ : revisiting the usual computation formulae. Journal of Plankton Research 19 (2), 263-271.

Lomas, M.W., Glibert, P.M., 1999. Temperature regulation of nitrate uptake: a novel hypothesis about nitrate uptake and reduction in cool-water diatoms. Limnology and Oceanography 44, 556-572.

MacDonald, R.W., McLaughlin, F.A., Wong, C.S., 1986. The storage of reactive silicate samples by freezing. Limnology and Oceanography 31, 1139-1142.

MacIsaac, J.J., Dugdale, R.C., Huntsman, S., Conway, H.L., 1979. The effects of sewage on uptake of inorganic nitrogen and carbon by natural populations of marine phytoplankton. Journal of Marine Research 37, 51-66.

Maguer, J.-F., L'Helguen, S., Madec, C., Labry, C., Le Corre, P., 2007. Nitrogen uptake and assimilation kinetics in Alexandrium minutum (Dinophyceae): effect of $\mathrm{N}$ limited growth rate on nitrate and ammonium interactions. Journal of Phycology 43, 295-303.

McCarthy, J.J., Taylor, W.R., Taft, J.L., 1977. Nitrogenous nutrition of the plankton in the Chesapeake Bay. 1. Nutrient availability and phytoplankton preferences. Limnology and Oceanography 22, 996-1011.

Mueller-Solger, A., Jassby, A.D., Muller-Navarra, D., 2002. Nutritional quality of food resources for zooplankton (Daphnia) in a tidal freshwater system (SacramentoSan Joaquin River Delta). Limnology and Oceanography 47, 1468-1476.

Parker, A.E., Yoshiyama, K., Sharp, J.H. Primary production estimates by the stable isotope 13c tracer technique: experimental considerations for work in estuaries. Estuaries and Coasts. Submitted for publication.

Parker, A.E., Dugdale, R.C., Foe, C., Wilkerson, F.P., Marchi, A., Drexel, J., Blaser, S. Fuller, J., 2009. Transport and fate of ammonium supply from a major urban wastewater treatment facility in the Sacramento River, CA. Coastal and Estuarine Research Federation Conference, Portland, OR.

Parker, A.E., Fuller, J., Dugdale, R.C., 2006. Estimating dissolved inorganic carbon concentrations from salinity in San Francisco Bay for use in ${ }^{14} \mathrm{C}-$ primary production studies. Interagency Ecological Program for the San Francisco Estuary 19, 17-22.

Parker, A.E., 2005. Differential supply of autochthonous organic carbon and nitrogen to the microbial loop of the Delaware Estuary. Estuaries 28 (6), 856-867.

Pauer, J.J., Auer, M.T., 2000. Nitrification in the water column and sediment of a hypereutrophic lake and adjoining river system. Water Research 34, 12471254.

Raven, J.A., Wollenweber, B., Handley, L.L., 1992. A comparison of ammonium and nitrate as nitrogen sources for photolithotrophs. New Phytologist 121, 19-32.

Revilla, M., Alexander, J., Glibert, P.M., 2005. Urea analysis in coastal waters: comparison of enzymatic and direct methods. Limnology and Oceanography Methods 3, 290-299.

Sharp, J.H., Yoshiyama, K., Parker, A.E., Schwartz, M.C., Curless, S., Beauregard, A. Ossolinski, J., Davis, A., 2009. A biogeochemical view of estuarine eutrophication: seasonal and spatial trends and correlations in the Delaware Estuary. Estuaries and Coasts 32, 1023-1043.

Sharp, J.H., 2001. Marine and aquatic communities, stress from eutrophication. Encyclopedia of Biodiversity, Academic Press 4, 1-11.

Sobczak, W.V., Cloern, J.E., Jassby, A.D., Cole, B.E., Schraga, T.S., Arnsberg, A., 2005. Detritus fuels ecosystem metabolism but not metazoan food webs in San Francisco estuary's freshwater Delta. Estuaries 28, 124-137.

Sommer, T., Armor, C., Baxter, R., Breuer, R., Brown, L., Chotkowski, M., Culberson, S. Feyer, F., Gingas, M., Herbold, B., Kimmerer, W., Mueller-Solger, A., Nobriga, M. Souza, K., 2007. The collapse of pelagic fishes in the upper San Francisco estuary. Fisheries 32, 270-277.

Solorzano, L., 1969. Determination of ammonia in natural waters by the phenol hypochlorite method. Limnology and Oceanography 14, 799-810.

Sverdrup, O., 1953. On the conditions for the vernal blooming of phytoplankton. Journal du Conseil International pour l' Exploration de la Mer 18, 287-295.

Syrett, P.J., 1981. Nitrogen metabolism of microalgae. In: Physiological basis of phytoplankton ecology. In: Platt, T. (Ed.), Canadian Bulletin of Fisheries and Aquatic Sciences. pp. 182-210. 
Van Nieuwenhuse, E., 2007. Response of summer chlorophyll concentrations to reduced total phosphorus concentration in the Rhine River (Netherlands) and the Sacramento-San Joaquin Delta (California). Canadian Journal of Fisheries and Aquatic Sciences 64, 1529-1542.

Waiser, M. Tumber, V. Holm, J. 2011. Effluent-dominated streams. Part 1: Presence and effects of excess nitrogen and phosphorus in Wascana Creek Saskatchewan, Canada. Environmental Toxicology and Chemistry 30, 496507.

Whitledge, T.E., Malloy, S., Patton, C.J., Wirick, C.D., 1981. Automated nutrient analysis in seawater. Brookhaven National Laboratory Tech. Rep. BNL 51398. 226pp.
Wilkerson, F.P., Dugdale, R.C., Hogue, V.E., Marchi, A., 2006. Phytoplankton blooms and nitrogen productivity in San Francisco Bay. Estuaries and Coasts 29, 401416.

Yool, A., Martin, A.P., Fernandez, C., Clark, D.R., 2007. The significance of nitrification for oceanic new production. Nature 447, 999-1002.

Xu, J., Glibert, P.M., Lin, H., Yin, K.D., Yuan, X., Chen, M., Harrison, P.J., 2011. Nitrogen sources and rates of phytoplankton uptake in different regions of Hong Kong waters in summer. Estuaries and Coasts. doi: 10.1007/s12237-011-9456-9.

Yoshiyama, K., Sharp, J.H., 2006. Phytoplankton response to nutrient enrichment in an urbanized estuary: apparent inhibition of primary production by overeutrophication. Limnology and Oceanography 51, 424-434. 